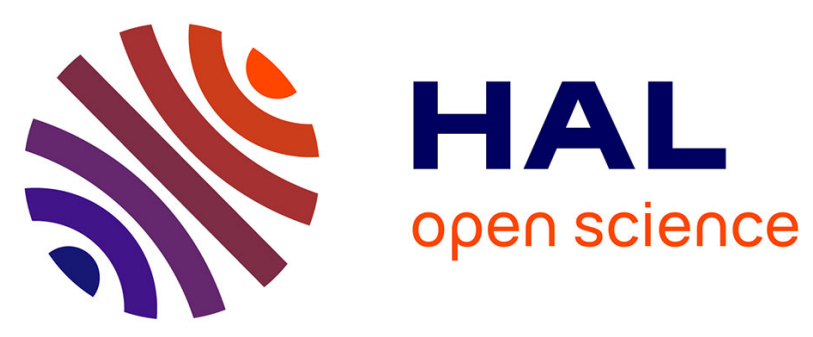

\title{
Pyropia orbicularis sp. nov. (Rhodophyta, Bangiaceae) based on a population previously known as Porphyra columbina from the central coast of Chile
}

Maria-Eliana Ramirez, Loretto Contreras-Porcia, Marie-Laure Guillemin, Juliet Brodie, Catalina Valdivia, María Rosa Flores-Molina, Alejandra Núñez, Cristian Bulboa Contador, Carlos Lovazzano

\section{To cite this version:}

Maria-Eliana Ramirez, Loretto Contreras-Porcia, Marie-Laure Guillemin, Juliet Brodie, Catalina Valdivia, et al.. Pyropia orbicularis sp. nov. (Rhodophyta, Bangiaceae) based on a population previously known as Porphyra columbina from the central coast of Chile. Phytotaxa, 2014, 158 (2), pp.133-153. hal-01138605

\section{HAL Id: hal-01138605 \\ https://hal.science/hal-01138605}

Submitted on 17 Apr 2015

HAL is a multi-disciplinary open access archive for the deposit and dissemination of scientific research documents, whether they are published or not. The documents may come from teaching and research institutions in France or abroad, or from public or private research centers.
L'archive ouverte pluridisciplinaire HAL, est destinée au dépôt et à la diffusion de documents scientifiques de niveau recherche, publiés ou non, émanant des établissements d'enseignement et de recherche français ou étrangers, des laboratoires publics ou privés. 
1 Pyropia orbicularis sp. nov. (Rhodophyta, Bangiaceae) based on a

2 population previously known as Porphyra columbina from the central

3 coast of Chile

4 MARÍA ELIANA RAMÍREZ ${ }^{1}$, LORETTO CONTRERAS-PORCIA ${ }^{2, *}$, MARIE-LAURE

5 GUILLEMIN ${ }^{3, *}$, JULIET BRODIE $^{4}$, CATALINA VALDIVIA $^{2}$, MARÍA ROSA FLORES-

6 MOLINA $^{5}$, ALEJANDRA NÚÑEZ ${ }^{2}$, CRISTIAN BULBOA CONTADOR ${ }^{6}$, CARLOS $^{-}$

$7 \quad$ LOVAZZANO $^{2}$

8
${ }^{1}$ Museo Nacional de Historia Natural, Área Botánica, Casilla 787, Santiago, Chile

${ }^{2}$ Departamento de Ecología y Biodiversidad, Facultad de Ecología y Recursos Naturales, Universidad Andres Bello, República 470, Santiago, Chile

${ }^{3}$ Instituto de Ciencias Ambientales y Evolutivas, Universidad Austral de Chile, Casilla 567 Valdivia, Chile

${ }^{4}$ Natural History Museum, Department of Life Sciences, Cromwell Road, London SW7 5BD, UK

${ }^{5}$ Instituto de Ciencias Marinas y Limnológicas, Facultad de Ciencias, Universidad Austral de Chile, Casilla 567, Valdivia, Chile

${ }^{6}$ Ingeniería en Acuicultura, Facultad de Ecología y Recursos Naturales, Universidad Andres Bello, República 470, 8370251 Santiago, Chile

${ }^{*}$ Corresponding authors: Loretto Contreras-Porcia lorettocontreras@ unab.cl. Marie-Laure Guillemin marielaure.guillemin@gmail.com
Mis en forme : Espagnol (Chili)

Code de champ modifié

Mis en forme : Espagnol (Chili)

Mis en forme : Espagnol (Chili) 
A new species of bladed Bangiales, Pyropia orbicularis sp. nov. M.E. Ramírez, L. Contreras-Porcia \& M.L. Guillemin, has been described for the first time from the central coast of Chile based on morphology and molecular analyses. The new species was incorrectly known as Porphyra columbina (now Pyropia columbina (Montagne) W.A. Nelson), and it can be distinguished from other species of Pyropia through a range of morphological characteristics, including the shape, texture and colour of the thallus, and the arrangement of the reproductive structures on the foliose thalli. Molecular phylogenies based on both the mitochondrial COI and plastid $r b c \mathrm{~L}$ gene regions enable this species to be distinguished from other species within Pyropia. Pyropia orbicularis sp. nov. belongs to a well supported clade of Pyropia from the southern oceans that include specimens from the South Pacific (North, South, Chatham, Stewart, Auckland, and Campbell Island, New Zealand; New South Wales, and Macquarie Island, Australia) including P. columbina and orbicularis sp. nov. and Pyropia sp. FIC from the Falkland Islands. 


\section{Introduction}

In a recent worldwide study of Bangiales (Rhodophyta) based on molecular analysis using nuclear (SSU rRNA) and chloroplast $r b c \mathrm{~L}$ regions, Sutherland et al. (2011) recognized the existence of fifteen genera of which seven are filamentous and eight foliose. Of the foliose genera, Porphyra sensu lato, which has representatives in all seas, has undergone many changes in its classification in the last decade (e.g. Anilkumar \& Rao 2005, Yoshida et al. 2005, Kikuchi et al. 2010, Nelson \& Broom 2010, Kucera \& Saunders 2012, Mateo-Cid et al. 2012, Nelson 2013).

The economic and cultural importance of Porphyra sensu lato is widely known and appreciated in Asian countries, notably Japan and China, North and South America, Australia and New Zealand (Aguilar-Rosas et al. 1998, Jian \& Chen 2001, He \& Yarish 2006, Blouin et al. 2011) and has been one of the red algal genera with the largest production and marketing worldwide. In Chile, species of the genus Pyropia and Porphyra, specifically the taxon known as Porphyra columbina Montagne (now Pyropia columbina (Montagne) W.A Nelson), are commonly called "luche or luchi" and have been harvested and consumed since the late Pleistocene by coastal populations in the country (Seguel \& Santelices 1988, Buschmann et al. 2001, González \& Santelices 2003, Dillehay et al. 2008). It is reported that the species, under the name $P$. columbina, is highly seasonal and grows abundantly between September-March along the upper intertidal zone of the Chilean coast from Arica $\left(18^{\circ} \mathrm{S}\right)$ to Tierra del Fuego $\left(55^{\circ} \mathrm{S}\right)$ (Ramírez \& Santelices 1991, Hoffman \& Santelices 1997). It is also known that this species may lose up to $90 \%$ of fresh weight during low tide (Contreras-Porcia et al. 2011) and several mechanisms of tolerance are activated during this adverse cellular condition in comparison with many other species 
(Contreras-Porcia et al. 2011, 2012, 2013; Flores-Molina et al. 2013). Nevertheless, the identity of the taxon "Porphyra columbina" in Chile has been questioned principally because (1) the majority of Chilean specimens to which this name has been applied belong to warm temperate localities (see discussion in Nelson \& Broom 2010) and (2) because the external morphology of specimens assigned to P. columbina in the Chilean coast is not consistent with the original description by Montagne (1842) or specimens recently reevaluated by Nelson \& Broom (2010). Thus, given their importance in ecophysiological studies, aquaculture management plans and biotechnological applications, it is crucial to classify this species and to be able to distinguish it from the many other foliose Bangiales, the majority of which are undescribed (J. Brodrie, L. Contreras, E. Macaya and M-L. Guillemin unpublished data) along the Chilean coast.

Molecular studies have revealed cryptic speciation within the genus Porphyra sensu lato (e.g. Broom et al. 1999, 2004, 2010, Brodie et al. 2007, Lindstrom 2008). Brodie et al. (in preparation), who sequenced samples of a foliose species assigned to "Porphyra columbina" collected from the length of the Chile coast, concluded, as had Sutherland et al. (2011), that there was no evidence of this species in the Chilean flora. They also concluded that of the foliose genera documented by Sutherland et al. (2011), three are present in Chile: Porphyra, Pyropia and Wildemania. Gross morphology within and between species is extremely diverse, varying from linear through ovate, to orbicular or funnel shaped, with entire or dentate, planar, undulate margins, and variable colour (yellow, olive green, brown and red-brown). In this context, and taking into account new molecular data gathered from 197 samples distributed from Arica $\left(18^{\circ} \mathrm{S}\right)$ to Tierra del Fuego $\left(55^{\circ} \mathrm{S}\right)(\mathrm{J}$. Brodrie, L. 
molecular data suggest the absence of $P$. columbina along the Chilean coast. The aim of the present study was to documents and clarifies the taxonomic status of one of these populations present on the Central coast of Chile (Maitencillo beach, Valparaíso) based on morphological and molecular analysis of COI and $r b c \mathrm{~L}$ genes.

\section{Materials and methods}

Collection of samples. A total of one hundred of Porphyra specimens previously identified as "Porphyra columbina" were collected from the upper and mid intertidal zone with low wave exposure along 300-500 m of coastline from Maitencillo beach, Valparaiso, Chile (32³9’S $71^{\circ} 26^{\prime} \mathrm{W}$ ) from March 2012 to January 2013. Samples were stored immediately in plastic bags containing seawater and transported to the laboratory in a cooler at $5-7{ }^{\circ} \mathrm{C}$. In the laboratory, algae were rinsed with $0.22 \mu \mathrm{m}$-filtered seawater and immediately pressed as herbarium vouchers. Subsamples were dried in desiccant silica gel (Vetec Analytical Reagents, Brazil) for subsequent DNA analysis, and other subsamples kept in filtered fresh seawater at $14 \pm 2{ }^{\circ} \mathrm{C}$, under a $30-50 \mu \mathrm{mol} \mathrm{m}^{-1} \mathrm{~s}^{-1}$ of photon flux density (Growth Chamber W-19, Amilab, Chile) prior to morphological analysis. The holotype specimen (MAI0007) was housed in the herbarium of the National Museum of Natural History, Chile under the number SGO162483. One isotype (MAI0006) was housed in the Colección de Flora y Fauna Prof. Patricio Sánchez Reyes (SSUC), Departamento de Ecología, Pontificia Universidad Católica de Chile (SSUC-7758).

Morphological observations. Thallus shape, colour, texture and rhizoid disposition was described from fifty plants. Also, microscopic observations of hand-cut transverse sections were used to determine the tissue thickness, number of cell layers and 
identification of reproductive structures. Dimensions of vegetative, rhizoidal cells and reproductive tissue (i.e. zygotosporangium and spermatangium) were measured and the number and size of zygotospores per zygotosporangium, and spermatia per spermatangium were recorded. Images were made using a Nikon Microscopy Unit (Nikon Corp. Tokyo, Japan) coupled to a digital recording system (CoolSNAP-Procf, Media Cybernetics, Silver Spring, MD, USA) and analyzed using the Image Pro Plus Version 4.5 software (Media Cybernetics, Silver Spring, MD, USA).

DNA extraction and amplification. Dried algal tissue was finely grounded in liquid nitrogen. DNA was extracted following the protocol described by Saunders (1993), slightly modified by Faugeron et al. (2001). COI-5P was amplified using the primer pair GazF1 (5'TCA ACA AAT CAT AAA GAT ATT GG -3') and GazR1 (5'-ACT TCT GGA TGT CCA AAA AAY CA -3'), following the amplification protocols of Saunders (2005). The chloroplastic gene $r b c \mathrm{~L}$, encoding the large subunit of the ribulose-1,5-bisphosphate carboxylase/oxygenase enzyme, was amplified using the primers F-rbcL (5' - TTG CAT AYG ATA TTG ATY TAT TTG AA-3') and R-rbcS (5'- RAG CTG TTT KTA AAG GWC CAC AA-3') and protocols published previously (Hommersand et al. 1994, Fredericq \& López-Bautista 2002). For both markers, PCR amplifications were performed in a Perkin Elmer Gene Amp PCR System 9700 (Applied Biosystems, Foster City, USA). All PCR products were purified using UltraClean ${ }^{\mathrm{TM}}$ DNA Purification kits (MO BIO Laboratories, Carlsbad, USA) and sequenced using the forward and the reverse amplification primers by Macrogen Inc. (Seoul, South Korea). Sequences were edited using Chromas v. 2.33 (McCarthy 1997) and alignments were obtained using the CLUSTAL function of Mega v 5 (Tamura et al. 2011). 
Sequences were obtained from 14 specimens (604 bp for the COI and $876 \mathrm{bp}$ for the $r b c \mathrm{~L})$ and deposited in GENBANK. Specimen collection information and GENBANK accession numbers are detailed in Table 1. In addition to the new sequences of Pyropia orbicularis sp. nov. obtained in this study, $57 \mathrm{COI}$ and $317 \mathrm{rbcL}$ sequences were retrieved from GENBANK for further analyses. A complete list of specimens used in the molecular analyses is detailed in Table S1.

Molecular analysis. Two data sets were created for the COI and the $r b c \mathrm{~L}$, respectively. Three species belonging to the genus Porphyra were used as outgroups (i.e. $P$. mumfordii, $P$. purpurea and $P$. umbilicalis, Table S1). Each sequence data set was partitioned according to codon position. The best-fit models were estimated independently for each partition by the Akaike Information Criteria (AIC) implemented in TREEFINDER (Jobb et al. 2004) and the parameters of the different substitution models were estimated independently for each partition. AIC identified $\mathrm{J} 2+\mathrm{G}$ model for the first codon position of the $r b c \mathrm{~L}, \mathrm{~J} 3+\mathrm{G}$ for the second codon position of the $r b c \mathrm{~L}, \mathrm{~J} 1+\mathrm{G}$ for the first codon position of the COI, GTR $+\mathrm{G}$ for the second codon position of the COI, and HKY for the third codon position of both genes. Phylogenetic relationships were inferred with a mixed model in a maximum likelihood framework by using TREEFINDER, version January 2008 (Jobb et al. 2004) and support for the nodes was assessed with 1,000 bootstrap pseudoreplicates.

Bayesian inference was performed using the general type of the best fit model parameters defined for each dataset using MrBayes v 3.1.2 (Huelsenbeck \& Ronquist 2001). Four independent analyses were run with four chains each, for five million generations. Trees and parameters were sampled every 1,000 generations and the default parameters were used to fit temperature and swapping. The first $25 \%$ of sampled trees were 
discarded as "burn-in" to ensure stabilization. The remaining trees were used to compute a consensus topology and posterior probability values.

Inter- and intraspecific uncorrected p-distances, were calculated in Mega v 5

(Tamura et al. 2011). Interspecific measures correspond to the pairwise distances between the Pyropia specimens used in the tree reconstruction; here the sequence of MAI0007 (i.e. holotype specimen, SGO162483) was used for Pyropia orbicularis sp. nov. Intraspecific sequence divergence was estimated in 12 species of Porphyra ( 2 for the COI and 12 for the $r b c \mathrm{~L}$, respectively) and 29 species of Pyropia (4 for the $\mathrm{COI}$ and 26 for the $r b c \mathrm{~L}$, respectively) for which multiple sequences were available in GENBANK (Table S1).

\section{Results}

Pyropia orbicularis [M.E. Ramírez, L. Contreras-Porcia \& M.L. Guillemin], sp. nov.

\section{(Figs 1-10, Fig. S1, Table 1-3)}

Type:-CHILE. Maitencillo beach, Valparaíso, $32^{\circ} 39^{\prime} \mathrm{S} 71^{\circ} 26^{\prime} \mathrm{W}$, coll. Contreras-Porcia, Núñez, Guajardo and Fierro, 12-10-2012, holotype: SGO162483 (Fig. 2), isotype: SSUC7758

Gametophyte blades orbicular, 2.8-14 cm high and 4-16 cm wide, with an irregular undulate margin; monostromatic, 36-139 $\mu \mathrm{m}$ thick in transverse section, attached to rocky substratum by abundant rhizoidal cells at the base of the thallus. Colour green-grey to brown on outer edges. Vegetative cells with a single stellate chloroplast. Monoecious; reproductive structures marginal; spermatiangial sori pale golden patches interspersed with 
deep red zygotosporangia and sterile cells; zygotosporangia in packets of a2/b2/c2 and spermatangia in packets of a4/b4/c4.

Habitat: -Upper and mid intertidal rock.

Etymology: - orbicularis for the typical shape of the blades, rounded or orbicular outline Molecular analysis: - For the chloroplast marker $r b c \mathrm{~L}$ (876 bp), only one haplotype was observed for the 13 sequenced individuals of Pyropia orbicularis sp. nov. Three haplotypes were detected for the mitochondrial marker COI, with 3 polymorphic sites along the 604 base pairs fragment sequenced (13 sequenced individuals, Table 1). Figures 9 and 10 show the maximum likelihood phylograms constructed with the $r b c \mathrm{~L}$ sequences of 89 Pyropia specimens, and the COI sequences of 34 Pyropia specimens, respectively. For both genes, tree topologies based on Bayesian and maximum likelihood analyses were largely congruent and shared comparable support values for major nodes (Figs 9 and 10).

For the COI, all specimens from Maitencillo beach form a strongly supported monophyletic lineage (support values $>99 \%$, Fig. 10). For the $r b c \mathrm{~L}$, the gene where the more complete data set is available, Pyropia orbicularis sp. nov. form a strongly supported monophyletic clade with Pyropia sp. FIC collected in Port Stanley in the East Falkland Island (Broom et al. 2010) (support values $>99 \%$, Fig. 9). The uncorrected p-distance between $P$. orbicularis sp. nov. and $P$. sp. FIC is of $0.57 \%$ for the $r b c \mathrm{~L}$ (i.e. 5 substitutions). Pyropia orbicularis sp. nov. is part of a well-supported clade encompassing 16 Pyropia species from the southern hemisphere that includes specimens from the Southern Ocean (King George Island), the South Atlantic (South Africa and Falkland Islands) and the South Pacific (North, South, Chatham, Stewart, Auckland, and Campbell Islands, New Zealand, New 
South Wales, and Macquarie Island, Australia) (Fig. 9). This southern hemisphere clade includes $P$. columbina (Nelson \& Broom 2010, Broom et al. 2010), where the uncorrected p-distance between $P$. orbicularis sp. nov. and $P$. columbina is of $3.11 \pm 0.54 \%$ for the $r b c \mathrm{~L}$ (i.e. $27.28 \pm 5.00$ substitutions). The COI data set did not allow to confirm the position of $P$. sp. FIC as the sister species of $P$. orbicularis $s p$. nov. within a southern hemisphere Pyropia clade owing to the low number of Pyropia COI sequences available in GENBANK (three times fewer than for the $r b c \mathrm{~L}$ ). Indeed, no COI sequences are available for the 15 other southern hemisphere species.

Interspecific divergences in the genus Pyropia (mean $12.81 \%$ for COI and $5.64 \%$ for the $r b c \mathrm{~L}$ ) are much deeper than the intraspecific divergences in both the genus Pyropia and Porphyra (mean $0.05 \%$ and $0.41 \%$ for COI and $0.09 \%$ and $0.17 \%$ for $r b c \mathrm{~L}$, for Pyropia and Porphyra, respectively) (Table 3). Between specimens of P. orbicularis sp. nov., intraspecific divergences for the COI range from $0.00 \%$ up to $0.66 \%$ while for the $r b c \mathrm{~L}$, where only one haplotype was detected, intraspecific divergences were of $0.00 \%$ (Table 3).

\section{Discussion}

The description of a new species of Pyropia, P. orbicularis sp. nov., resolves the identity of the species misidentified as Porphrya columbina, now Pyropia columbina (Montagne)

W.A. Nelson, from the population Maitencillo beach; central coast of Chile. Pyropia orbicularis sp. nov. and P. columbina exhibit morphological differences in both the shape and length of the thallus. The gametophyte thallus of $P$. orbicularis reaches a size of $14 \mathrm{~cm}$, while that of $P$. columbina reaches up to $5 \mathrm{~cm}$ (Montagne 1842, Nelson \& Broom 2010). Both species are distinguishable by the colour and thickness of the blade. P. columbina has 
a pink-gray colour (Nelson \& Broom 2010), and a thin thallus $(75-90 \mu \mathrm{m})$, whereas $P$. orbicularis is green-grey to brown in colour and has a thick thallus $(36-139 \mu \mathrm{m})$.

These morphological differences are congruent with the molecular data, as measured using the $\mathrm{COI}$ and $r b c \mathrm{~L}$ markers. Despite both species being positioned within a clade conformed of several Pyropia species from the Southern Pacific, the divergence between P. orbicularis and $P$. columbina is up to $3 \%$. Geographically, $P$. columbina has, until now, been confined to the temperate, cold waters of New Zealand's sub-Antarctic Auckland and Campbell Islands, the Antipodes Islands, and the Falkland Islands. The apparent limitation of the distribution of $P$. columbina up to $51^{\circ} \mathrm{S}$ raises questions about the reports of this species on the central coast of Chile. Another species which is close to P. orbicularis in our phylogenetic analysis is the recently described Pyropia plicata W.A. Nelson from the New Zealand region, distributed in the North, South and Chatham Islands (Nelson 2013).

However, this species is different from $P$. orbicularis primarily in the configuration of the reproductive regions (Table 2).

With molecular phylogenetic analysis, sequences of $P$. orbicularis from Chile were shown to be similar to the species coded as Pyropia sp. FIC from the Falkland Islands (Broom et al. 2010). The values of uncorrected p-distance for the $r b c \mathrm{~L}$ between $P$. orbicularis and Py. FIC (0.57\%) are low and fall within the limit of the Pyropia intraspecific genetic distance for this gene $(0.00 \%-0.82 \%$, Table 3). Broom et al. (2010) described some morphological characteristics of the thallus from Pyropia sp FIC that coincide with the descriptions of P. orbicularis from Maintencillo beach (e.g. male and female regions of the blade intermixed; had a brownish-red thallus), which could validate the inclusion of $P$. FIC within $P$. orbicularis. However, as only one locality has been 
sampled and only one $r b c \mathrm{~L}$ haplotype is available for both species it is premature to consider that Pyropia sp. FIC of the Falkland Islands is conspecific with Pyropia orbicularis sp. nov. Considering the large latitudinal gradient along the Pacific coast of Chile, where $P$. columbina was previously reported, a more detailed study of $P$. orbicularis $s p$. nov. is needed in order to better determine the amount of genetic diversity present within this species and to delimit its latitudinal range. In addition, a more detailed molecular and morphological analysis of the Bangiales flora from Chile will be necessary to unravel the possible presence of cryptic diversity along the South Eastern, Pacific coast.

\section{Acknowledgments}

This work was supported by DI-59-12/R and FONDECYT 1120117 to L.C-P., and INACH T_16-11 to ML.G. We are especially grateful to E. Guajardo, C. Fierro, J. Zapata and A. Contreras for their fieldwork assistance and to V. Flores, J. Reyes, G. Peralta and D. Pérez for technical support. Also, we appreciate the constructive comments from the Editor and from anonymous reviewers that helped improved the manuscript.

\section{References}

Aguilar-Rosas, R., Espinoza-Ávalos, J. \& Aguilar-Rosas, L.E. (1998) Uso de las algas marinas en México. Ciencia y Desarrollo 24: 65-73. 
Anilkumar, C. \& Rao, P.S.N. (2005) A new species of Porphyra (Rhodophyta, Bangiales) from the Malvan coast of Maharashtra (India). Feddes Repertorium 116: 222-225. DOI: 10.1002/fedr.200411069

Blouin, N.A., Brodie, J.A., Grossman, A.C., Xu, P. \& Brawley, S.H. (2011) Porphyra: a marine crop shaped by stress. Trends in Plant Science 16: 29-37. DOI:

10.1016/j.tplants.2010.10.004

Brodie, J., Bartsch, I., Neefus, C., Orfanidis, S., Bray, T. \& Mathieson, A.C. (2007) New insights into the cryptic diversity of the North Atlantic-Mediterranean 'Porphyra leucosticta' complex: P.olivii sp. nov. and P. rosengurttii (Bangiales, Rhodophyta). European Journal of Phycology 42: 3-28. DOI: 10.1080/09670260601043946

Broom, J.E., Jones, W.A., Hill, D.F., Knight, G.A. \& Nelson. W.A. (1999) Species recognition in New Zealand Porphyra using 18S rDNA sequencing. Journal of Applied Phycology 11: 421-428. DOI: 10.1023/A:1008162825908

Broom, J.E.S., Farr, T.J. \& Nelson, W.A. (2004) Phylogeny of the Bangia flora of New Zealand suggests a southern origin for Porphyra and Bangia (Bangiales, Rhodophyta). Molecular Phylogenetics and Evolution 31: 1197-1207. DOI:

10.1016/j.ympev.2003.10.015

Broom, J.E.S., Nelson, W.A., Farr, T.J., Phillips, L.E. \& Clayton, M. (2010) Relationships of the Porphyra (Bangiales, Rhodophyta) flora of the Falkland Islands: a molecular survey using $r b c \mathrm{~L}$ and nSSU sequence data. Australian Systematic Botany 23: 27-37. DOI:

$10.1071 /$ SB09033 
Buschmann, A.H., Correa. J.A., Westermeier, R., Hernández-González, M. \& Norambuena, R. (2001) Cultivation of red algae in Chile: a review. Aquaculture 194: 203-220. DOI:

\subsection{6/S0044-8486(00)00518-4}

Contreras-Porcia, L., Flores, V., Thomas, D. \& Correa, J.A. (2011) Tolerance to oxidative stress induced by desiccation in Porphyra columbina (Rhodophyta). Journal of

Experimental Botany 62: 1815-1829. DOI: 10.1093/jxb/erq364

Contreras-Porcia, L., Callejas, S., Thomas, D., Sordet, C., Pohnert, G., Contreras, A., Lafuente, A., Flores-Molina, M.R. \& Correa, J.A. (2012) Seaweeds early development: detrimental effects of desiccation and attenuation by algal extracts. Planta 235: 337-348. DOI: $10.1007 / \mathrm{s} 00425-011-1512-y$

Contreras-Porcia, L., López-Cristoffanini, C., Lovazzano, C., Flores-Molina, M.R., Thomas, D., Núñez, A., Fierro, C., Guajardo, E., Correa, J.A., Kube, M. \& Reinhardt, R. (2013) Differential gene expression in Pyropia columbina (Bangiales, Rhodophyta) under natural hydration and desiccation conditions. Latin America Journal of Aquatic Research, in press

Dillehay, T. D., Ramirez, C., Pino, M., Collins, M., Rossen, J. \& Pino-Navarro, D. (2008) Monte Verde: Seaweeds, food, and medicine and the peopling of the Americas. Science 325: $1287-89$.

Faugeron, S., Valero, M., Destombe, C., Martínez, E.A. \& Correa, J.A, (2001) Hierarchical spatial structure and discriminant analysis of genetic diversity in the red alga Mazzaella laminarioides (Gigartinales, Rhodophyta). Journal of Phycology 37: 705-716. 
Flores-Molina, M.R., Thomas, D.; Lovazzano, C.; Núñez, A.; Zapata, J.; Kumar, M.;

Correa, J.A.; Contreras-Porcia, L. (2013) Desiccation stress in intertidal seaweeds: Effects on morphology, antioxidant responses and photosynthetic performance. Aquatic Botany, DOI: 10.1016/j.aquabot.2013.11.004.

Fredericq, S. \& Lopez-Bautista, J. (2002) Characterization and phylogenetic position of the red alga Besa papillaeformis Setchell: an example of progenetic heterochrony? Constancea, 83.

González, A. \& Santelices, B. (2003) A re-examination of the potential use of central Chilean Porphyra (Bangiales, Rhodophyta) for human consumption. In: Chapman A.R.O., Anderson R.J., Vreeland V.J. \& Davidson I. (eds) Proceedings of the 17th International Seaweed Symposium. Oxford University Press Inc., NY, USA, pp. 249-255.

He, P. \& Yarish, C. (2006) The developmental regulation of mass cultures of free-living conchocelis for commercial net seeding of Porphyra leucosticta from Northeast America. Aquaculture 257: 373-381. DOI: 10.1016/j.aquaculture.2006.03.017

\section{Hoffmann, A. \& Santelices, B. (1997) Flora marina de Chile Central. Ediciones}

Universidad Católica de Chile. Santiago, Chile, 434 pp.

Hommersand, M.H., Fredericq, S. \& Freshwater, D.W. (1994) Phylogenetic systematics and biogeography of the Gigartinaceae (Gigartinales, Rhodophyta) based on sequence analysis of rbcL. Botanica Marina 37:193-203.

Huelsenbeck, J,P \& Ronquist, F. (2001) MRBAYES: Bayesian inference of phylogeny. Bioinformatics, 17:754-755. 
Jian, J. \& Chen, J. (2001) Sea Farming and Sea Ranching in China. FAO Fisheries Technical Paper No. 418, FAO, Rome, Italy, 71 pp.

Jobb, G., Von Haeseler, A. \& Strimmer, K. (2004) TREEFINDER: a powerful graphical analysis environment for molecular phylogenetics. BMC Evolutionary Biology 4:18.

Kikuchi, N., Arai, S., Yoshida, G., Shin, J.-A., Broom, J.E., Nelson, W.A. \& Miyata, M. (2010). Porphyra migitae sp. nov. (Bangiales, Rhodophyta) from Japan. Phycologia 49: 345-354.

Kucera, H. \& Saunders, G.W. (2012) A survey of Bangiales (Rhodophyta) based on multiple molecular markers reveals cryptic diversity. Journal of Phycology 48: 869-882. DOI: $10.1111 / \mathrm{j} .1529-8817.2012 .01193 . x$

Lindstrom, S.C. (2008) Cryptic diversity, biogeography and genetic variation in Northeast Pacific species of Porphyra sensu lato (Bangiales, Rhodophyta). Journal of Applied Phycology 20: 951-962. DOI: 10.1007/s10811-008-9313-9

Mateo-Cid, L.E., Mendoza-González, A.C., Díaz-Larrea, J., Sentíes, A., Pedroche, F.F. \& Sánchez, J. (2012) A new species of Pyropia (Rhodophyta, Bangiaceae), from the Pacific coast of Mexico, based on morphological and molecular evidence. Phytotaxa 54: 1-12.

McCarthy, C. (1997) Chromas, Version 1.41. Brisbane, Queensland: Griffith University. Montagne, C. (1842) Prodromus generum specierumque phycearum novarum. In Itinere ad polum antarcticum...ab illustri Dumont d'Urville peracto collectarum, notis diagnosticis tantum huc evulgatarum, descriptionibus verò fusioribus nec no iconibus analyticis jam jamque illustrandarum. Paris, pp. 1-16. 
Montagne, C. (1845) Plantes cellulaires. In: Hombron, J.B. \& Jacquinot H. (eds) Voyage au Pôle Sud et dans l'Océanie sur les corvettes l'Astrolabe et la Zelée...pendant les années 1837-1838-1839-1840, sous le commandement de M. J. Dumontd'Urville. Botanique. Vol. 1. Paris, i-xiv, pp. 1-349.

Nelson, W.A. \& Broom, J. (2010) The identity of Porphyra columbina (Bangiales, Rhodophyta) originally described from the New Zealand subantarctic islands. Australian Systematic Botany 23: 16-26. DOI: 10.1071/SB09032

Nelson, W.A. (2013) Pyropia plicata sp. nov. (Bangiales, Rhodophyta): naming a common intertidal alga from New Zealand. PhytoKeys 21: 17-28. DOI: 10.3897/phytokeys.21.4614

Ramírez., M.E. \& Santelices, B. (1991) Catálogo de las algas marinas bentónicas de la costa temperada del Pacífico de Sudamérica. Monografías Biológicas 5: 1-437.

Saunders, G.W. (1993) Gel purification of red algal genomic DNA: an inexpensive and rapid method for the isolation of polymerase-chain reaction-friendly DNA. Journal of Phycology 29: 251-254.

Saunders, G.W. (2005) Applying DNA barcoding to red macroalgae: a preliminary appraisal holds promise for future applications. Philosophical Transactions of the Royal Society B 360: 1879-1888.

Seguel, M. \& Santelices, B. (1988) Cultivo masivo de la fase conchocelis de luche, Porphyra columbina Montagne (Rhodophyta, Bangiaceae). Gayana Botanica 45: 317-327.

Sutherland, J.E., Lindstrom, S.C., Nelson, W.A., Brodie, J., Lynch, M.D.J., Hwang, M.S., Choi, H.G., Miyata, M., Kikuchi, N., Oliveira, M.C., Farr, T., Neefus, C., Mols-Mortensen, 
A., Milstein, D. \& Müller, K.M. (2011) A new look at an ancient order: generic revision of the Bangiales (Rhodophyta). Journal of Phycology 47: 1131-1151. DOI: 10.1111/j.15298817.2011.01052.x

Tamura, K., Peterson, D., Peterson, N., Stecher, G., Nei, M.\& Kumar, S. (2011) MEGA5: Molecular Evolutionary Genetics Analysis using Maximum Likelihood, Evolutionary

Distance, and Maximum Parsimony Methods. Molecular Biology and Evolution 28: 27312739.

Yoshida, T., Shimada, S., Yoshinaga, K. \& Nakajima, Y. (2005) Checklist of marine algae of Japan. Japanese Journal of Phycology 53: 179-228. 

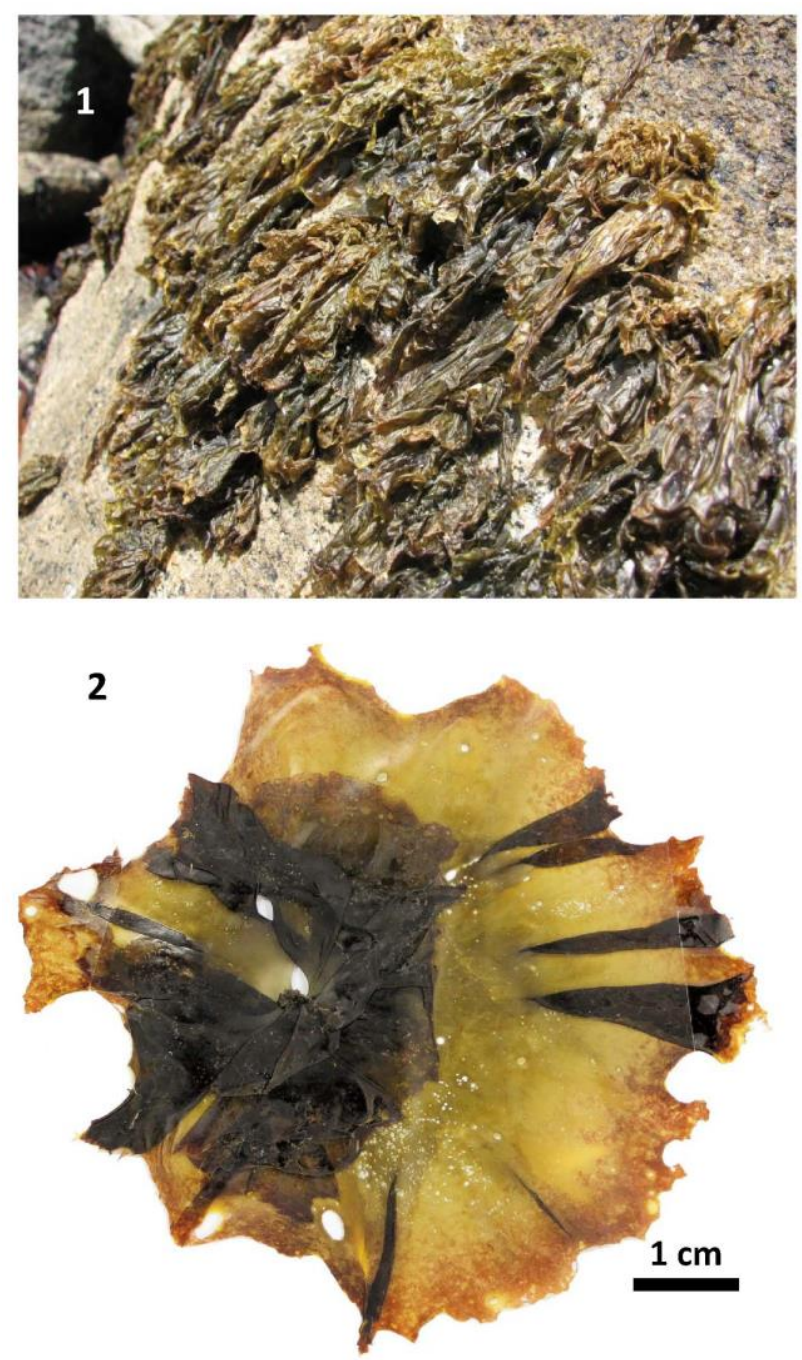

FIGURES 1-2. Pyropia orbicularis sp. nov. Fig.1. Habit of the foliose gametophyte from

391 the upper intertidal zone from Maitencillo beach, Valparaiso, Chile. Fig. 2. Holotype specimen of Pyropia orbicularis sp. nov. SGO162483, collected from the upper intertidal zone of Maitencillo beach, Valparaíso, Chile. 

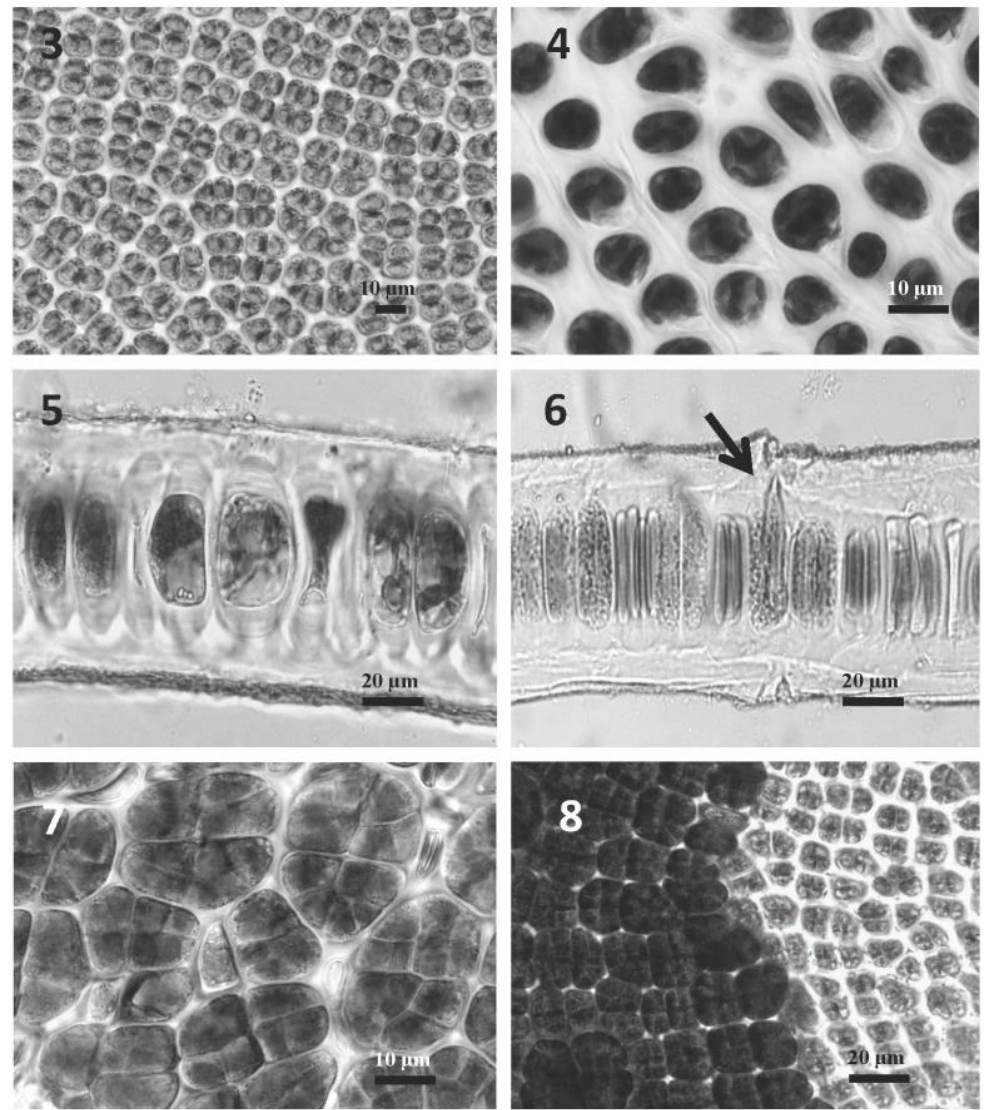

395

FIGURES 3-8. Vegetative and reproductive characteristics of Pyropia orbicularis sp. nov.

Fig. 3. Surface view of vegetative region of the thallus. Fig. 4. Surface view of basal, rhizoidal cells. Fig. 5. Cross-section of vegetative region of thallus. Fig. 6. Trichogyne (arrow). Fig. 7. Surface view of zygotosporangia. Fig. 8. Fertile region of the blade with packets of developing zygotosporangia (larger) and packets of spermatangia (smaller). 


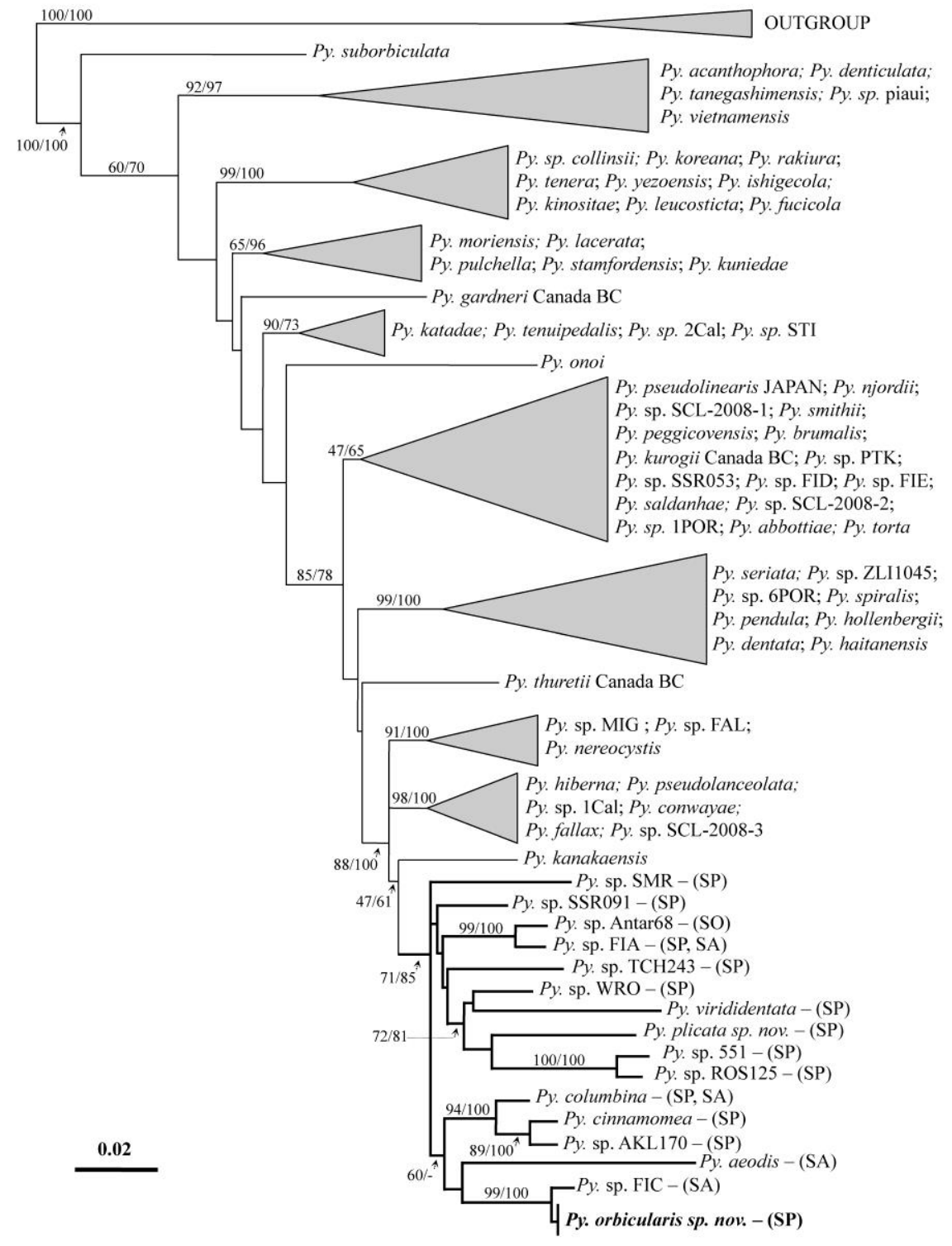


FIGURE 9. Maximum likelihood rooted tree for $r b c \mathrm{~L}$ sequences ( $876 \mathrm{bp}$ ) of Pyropia. Porphyra mumfordii, $P$. purpurea and $P$. umbilicalis, were used as outgroups. For each node, Maximum Likelihood bootstrap values and Bayesian Posterior Probabilities are indicated (ML/BPP). Only high support values (>60) are shown; - = clade not observed in the Bayesian Inference. Next to collapsed branches are abbreviated species or sequences names, GENBANK accession numbers have been omitted for brevity but are listed in Table S1 (Supporting Information, sequences highlighted in grey). Region where specimens were collected are indicated within parenthesis: $\mathrm{SA}=$ South Atlantic, $\mathrm{SP}=$ South Pacific, $\mathrm{SO}=$ Southern Ocean. Thick lines highlight the southern hemisphere clade that include Pyropia orbicularis sp. nov. 


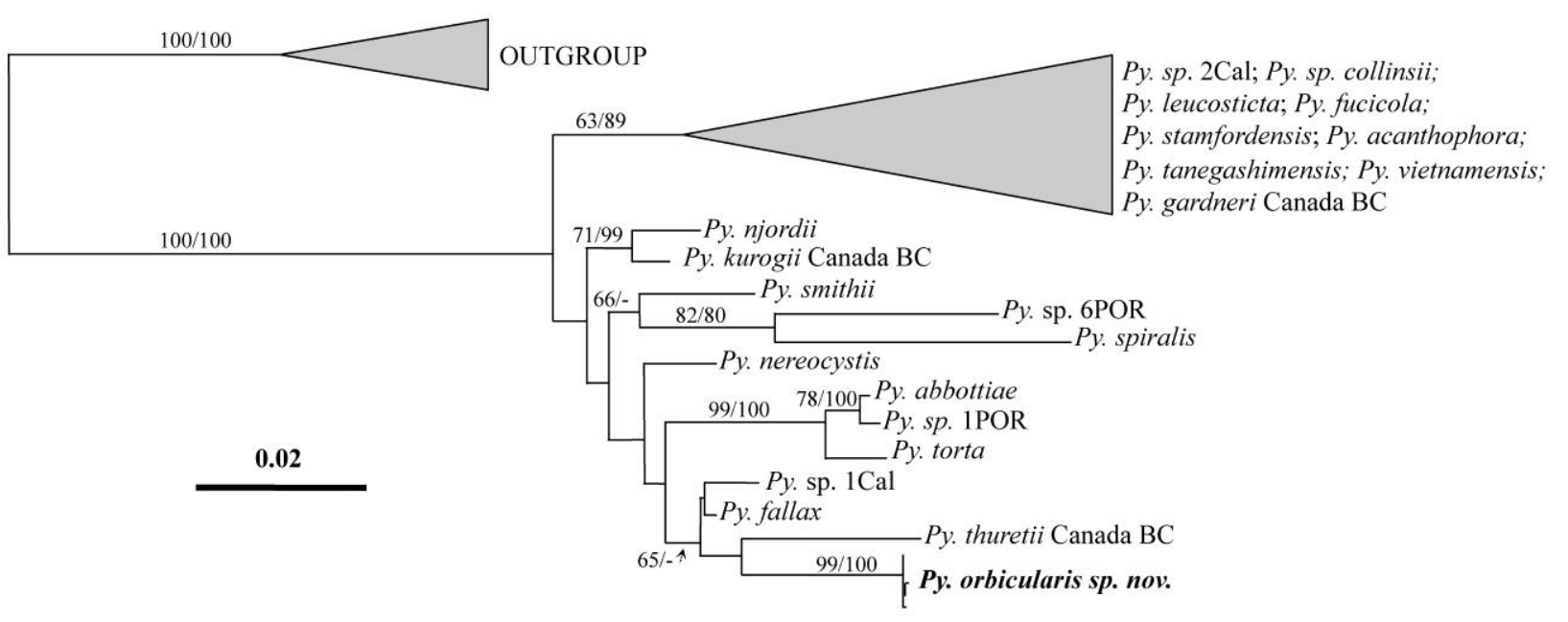

413 FIGURE 10. Maximum likelihood rooted tree for COI sequences (604 bp) of Pyropia. Porphyra mumfordii, P. purpurea and $P$.

414 umbilicalis, were used as outgroups. For each node, Maximum Likelihood bootstrap values and Bayesian Posterior Probabilities are

415 indicated (ML/BPP). Only high support values (>60) are shown; - = clade not observed in the Bayesian Inference. Next to collapsed

416 branches are abbreviated species or sequences names, GENBANK accession numbers have been omitted for brevity but are listed in

417 Table S1 (Supporting Information, sequences highlighted in grey). 
418 TABLE 1: Specimen collection information, voucher number and GenBank accession numbers of individuals from Maitencillo beach,

419 Valparaíso, Chile, sequenced during this work. See morphological features in Supporting Information (Fig. S1)

\begin{tabular}{|c|c|c|c|c|}
\hline \multirow[t]{2}{*}{ Taxon } & \multirow[t]{2}{*}{ Collection data } & \multirow[t]{2}{*}{$\begin{array}{l}\text { Sample coding/ voucher } \\
\text { number }\end{array}$} & \multicolumn{2}{|c|}{$\begin{array}{c}\text { GenBank accession } \\
\text { numbers }\end{array}$} \\
\hline & & & COI & $r b c \mathbf{L}$ \\
\hline \multirow{14}{*}{$\begin{array}{l}\text { Pyropia orbicularis } s p \text {. } \\
\text { nov. }\end{array}$} & 02/01/2012. Collector: MR. Flores-Molina; A. Nuñez. & MAI0101 & KF479515 & KF479481 \\
\hline & 02/01/2012. Collector: MR. Flores-Molina; A. Nuñez. & MAI0102 & - & KF479482 \\
\hline & 02/01/2012. Collector: MR. Flores-Molina; A. Nuñez. & MAI0103 & KF479516 & - \\
\hline & 10/12/2012. Collector: E. Guajardo, L. Contreras-Porcia, C. & MAI0001 & KF479502 & KF479484 \\
\hline & Fierro \& A. Nuñez & & & \\
\hline & 10/12/2012. Collector: E. Guajardo, L. Contreras-Porcia, C. & MAI0002 & KF479503 & KF479485 \\
\hline & Fierro \& A. Nuñez & & & \\
\hline & 10/12/2012. Collector: E. Guajardo, L. Contreras-Porcia, C. & MAI0003 & KF479504 & KF479486 \\
\hline & Fierro \& A. Nuñez & & & \\
\hline & 10/12/2012. Collector: E. Guajardo, L. Contreras-Porcia, C. & MAI0005 & KF479505 & KF479488 \\
\hline & Fierro \& A. Nuñez & & & \\
\hline & $\begin{array}{l}\text { 10/12/2012. Collector: E. Guajardo, L. Contreras-Porcia, C. } \\
\text { Fierro \& A. Nuñez }\end{array}$ & MAI0006/ SSUC-7758 & KF479506 & KF479489 \\
\hline & $\begin{array}{l}\text { 10/12/2012. Collector: E. Guajardo, L. Contreras-Porcia, C. } \\
\text { Fierro \& A. Nuñez }\end{array}$ & MAI0007/ SGO162483 & KF479507 & KF479490 \\
\hline & $\begin{array}{l}\text { 10/12/2012. Collector: E. Guajardo, L. Contreras-Porcia, C. } \\
\text { Fierro \& A. Nuñez }\end{array}$ & MAI0008 & KF479508 & KF479491 \\
\hline
\end{tabular}


10/12/2012. Collector: E. Guajardo, L. Contreras-Porcia, C.

Fierro \& A. Nuñez

10/12/2012. Collector: E. Guajardo, L. Contreras-Porcia, C.

Fierro \& A. Núñez

10/12/2012. Collector: E. Guajardo, L. Contreras-Porcia, C.

Fierro \& A. Núñez

10/12/2012. Collector: E. Guajardo, L. Contreras-Porcia, C

Fierro \& A. Núñez

\begin{tabular}{lll} 
MAI0009 & KF479509 & KF479492 \\
MAI0014 & KF479512 & KF479497 \\
MAI0015 & KF479513 & KF479498 \\
MAI0016 & KF479514 & KF479499 \\
& & \\
\hline
\end{tabular}


422 TABLE 2: Morphological features of Pyropia orbicularis sp. nov. from Maitencillo beach,

423 Valparaiso, Chile, Pyropia columbina and Pyropia plicata.

\begin{tabular}{|c|c|c|c|}
\hline Feature & $\begin{array}{l}\text { Pyropia orbicularis sp. } \\
\text { nov. }\end{array}$ & Pyropia columbina $^{1,2}$ & Pyropia plicata $^{3}$ \\
\hline Size blade (cm, diameter) & $4-16$ & $<5$ & $4-12$ \\
\hline Shape & Orbicular & Rosette to ovate & Circular to oval \\
\hline Color & Green-brown & Purple to grey & Purple to grey \\
\hline Habitat & $\begin{array}{l}\text { Upper-mid intertidal } \\
\text { zone }\end{array}$ & Intertidal zone & $\begin{array}{l}\text { Upper-mid intertidal } \\
\text { zone }\end{array}$ \\
\hline Seasonality & Year-round & Year-round & Year-round \\
\hline Sexuality & Monoecious & Monoecious & Monoecious \\
\hline Vegetative thickness $(\mu \mathrm{m})$ & $36-139$ & $75-90$ & $50-55$ \\
\hline Reproductive thickness $(\mu \mathrm{m})$ & $31-188$ & - & $60-110$ \\
\hline $\begin{array}{l}\text { Vegetative cells } \\
(\mu \mathrm{m}, \text { length } \times \text { width })\end{array}$ & $18-42 \times 10-36$ & - & - \\
\hline $\begin{array}{l}\text { Rhizoidal cells } \\
(\mu \mathrm{m}, \text { length } \times \text { width })\end{array}$ & $26-54 \times 17-38$ & - & - \\
\hline Spermatangium & $\mathrm{a} 4 / \mathrm{b} 4 / \mathrm{c} 4$ & $\mathrm{a} / 4, \mathrm{~b} / 4, \mathrm{c} / 8-16$ & $\mathrm{a} / 2, \mathrm{~b} / 2, \mathrm{c} / 8$ \\
\hline Zygotosporangium & $\mathrm{a} 2 / \mathrm{b} 2 / \mathrm{c} 2$ & $\mathrm{a} / 4-8, \mathrm{~b} / 4-8$ & $\mathrm{a} / 8, \mathrm{~b} / 8, \mathrm{c} / 8$ \\
\hline
\end{tabular}

${ }^{1}$ Referred to (Nelson and Broom 2010) and ${ }^{2}$ (Montagne 1842).

${ }^{3}$ Referred to (Nelson 2013). 
431 TABLE 3: Intra- and inter-specific uncorrected p-distance - in percent - in Porphyra and Pyropia.

432

\begin{tabular}{lcc|cc}
\hline & \multicolumn{2}{c|}{ COI (604 bp.) } & \multicolumn{2}{c}{$r b c \mathbf{L}(\mathbf{8 7 6}$ bp.) } \\
\hline & $\begin{array}{c}\text { Nb. of pairwise } \\
\text { comparisons }\end{array}$ & $\begin{array}{c}\text { p-distance (\%) Mean } \pm \\
\text { SD (Min-Max) }\end{array}$ & $\begin{array}{l}\text { Nb. of pairwise } \\
\text { comparisons }\end{array}$ & $\begin{array}{l}\text { p-distance }(\%) \text { Mean } \pm \\
\text { SD (Min-Max) }\end{array}$ \\
\hline Intraspecific diversity - Porphyra & 72 & $0.41 \pm 0.23(0.00-1.15)$ & 584 & $0.17 \pm 0.20(0.00-0.71)$ \\
Intraspecific diversity - Pyropia & 67 & $0.05 \pm 0.09(0.00-0.39)$ & 938 & $0.09 \pm 0.16(0.00-0.82)$ \\
Intraspecific diversity - & 78 & $0.17 \pm 0.18(0.00-0.66)$ & 78 & $0.00 \pm 0.00(0.00-0.00)$ \\
Pyropia orbicularis sp. nov. & & & & \\
\hline Interspecific diversity - Pyropia & 231 & $12.81 \pm 2.59(2.48-17.97)$ & 2926 & $5.64 \pm 1.59(0.00-10.16)$ \\
\hline
\end{tabular}

433

434 
440 TABLE S1. Specimen collection information, sequence length and GenBank accession numbers of sequences of COI and $r b c \mathrm{~L}$ used in 441 the analyses. Specimens are in alphabetical order. Sequences used in ML and IB tree reconstruction are highlighted in grey.

Taxon

Collection location

COI

$r b c \mathrm{~L}$

$\mathrm{COI}$

$r b c \mathrm{~L}$

\section{Porphyra}

Porphyra cuneiformis

Porphyra cuneiformi

Juneau, AK, USA

1411

Salt lake outlet, Russian Harbor, Kodiak Island, Alaska, USA

Porphyra cuneiformi

Humpback Bay, Unalaska Island, Alaska, USA

Porphyra cuneiformis

Iniskin Bay, Cook Inlet, Alaska, USA

Porphyra cuneiformis

Kake Ferry Terminal, Alaska, USA

Porphyra dioica

Lanyon Bay, Glamorgan, Wales, UK

Porphyra dioica

Sandon, Orkney, Scotland, UK

Porphyra dioica

Talmine, Sutherland, Scotland, UK

Porphyra dioica

Sidmouth, Devon, England, UK

Porphyra dioica

Sidmouth, UK

Porphyra dioica

North of Aberystwyth, Wales, UK

1411

1198

1161

1161

1324

537

537

539

539

1387

1424
$\mathrm{AF} 452428$

EU223049

EU223051

EU223053

EU223055

DQ442888

DQ442889

DQ191339

DQ191340

HQ687546

AF081291 


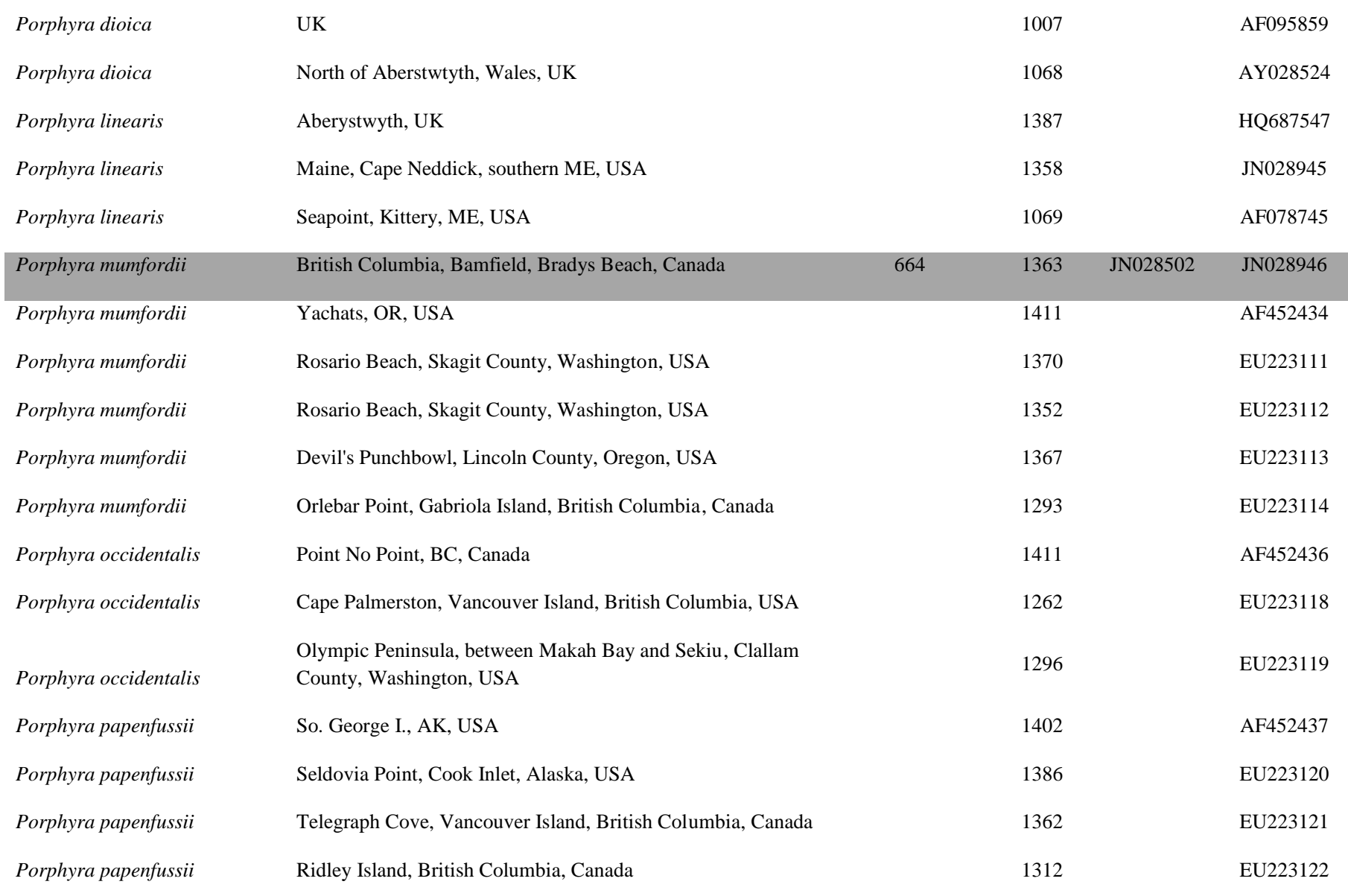




Porphyra purpurea
Porphyra purpurea

Porphyra purpurea

Porphyra purpurea

Porphyra purpurea

Porphyra purpurea

Porphyra purpurea

Porphyra purpurea

Porphyra purpurea

Porphyra sp. olivii

Porphyra sp. olivii

Porphyra sp. olivii

Porphyra sp. olivii

Porphyra sp. olivii

Porphyra sp. SCL-2008-4

Porphyra sp. SCL-2008-4

Porphyra sp. SCL-2008-5

Porphyra sp. SCL-2008-5
New Brunswick, Richebucto Cape Breakwater, Canada

Litstock, Somerset, UK

Avonport, Nova Scotia,Canada

Herring Cove, Nova Scotia,Canada

Light House Cove, Dipper Harbor, New Brunswick, Canada

Leighton Cove, Whiting, ME, USA

Leighton Cove, Whiting, ME, USA

Camp Ellis, Saco, ME, USA

Camp Ellis, Saco, ME, USA

Taverna Chara, Thessaloniki Gulf, Greece

N. Krini, Thessaloniki Gulf, Greece

Dover Point, NH, USA

Yacht Club, Hull, MA, USA

Hammonasset State Park, CT, USA

Akutan Harbor, Akutan Island, Alaska, USA

Akutan Harbor, Akutan Island, Alaska, USA

Creyke Point, Strait of Juan de Fuca,British Columbia, Canada

Nudibranch Point, Barkley Sound, British Columbia, Canada

$1363 \quad$ JN028518 JN028949

1387

HQ687516

1049

AY028533

1049

AY028532

AY028535

AF078746

AY028534

AY028536

AY028537

DQ837007

DQ837008

DQ813625

DQ813617

DQ813611

EU223240

EU223242

EU223184

EU223185 
Fishboat Bay, Strait of Juan de Fuca, Canada

EU223190

Porphyra sp. SCL-2008-5

Sombrio Beach, Strait of Juan de Fuca, British Columbia, Canada

Porphyra sp. SCL-2008-5

Botany Bay, Strait of Juan de Fuca, British Columbia, Canada

EU223191

Porphyra sp. SCL-2008-5

Halibut Point, Sitka Sound, Alaska, USA

Porphyra sp. SCL-2008-5

Porphyra sp. SCL-2008-5

Akutan Point, Akutan Island, Alaska, USA

Akutan Point, Akutan Island, Alaska, USA

1349

EU223192

EU223193

1351

EU223194

Clover Point, Victoria, British Columbia, Canada

EU223195

Porphyra sp. SCL-2008-5

Porphyra sp. SCL-2008-5

Porphyra sp. SCL-2008-5

Porphyra sp. SCL-2008-5

Yugnat Rocks, Katmai National Park, USA

EU223196

Akutan Point, Akutan Island, Alaska, USA

EU223197

EU223198

Seppings Island, Barkley Sound, British Columbia, Canada

EU223199

Amalik Bay, Katmai National Park, Alaska, USA

EU223200

Cape Palmerston, Vancouver Island, British Columbia, USA

EU223201

Port Dick, Kenai Peninsula, Alaska, USA

EU223202

Pumicestone Bay, Unalaska Island, Alaska, USA

EU223203

Porphyra sp. SCL-2008-5

Porphyra sp. SCL-2008-5 
Porphyra umbilicalis

Faroe Islands 


\begin{tabular}{|c|c|c|c|c|c|}
\hline Porphyra umbilicalis & Easdale, Kintyre, Scotland, UK & 537 & & DQ442891 & \\
\hline Porphyra umbilicalis & $\begin{array}{l}\text { Crawfordsburn, Belfast Lough, Co. Down, Northern Ireland, } \\
\text { UK }\end{array}$ & 539 & & DQ191334 & \\
\hline Porphyra umbilicalis & Sidmouth, Devon, England, UK & 539 & & DQ191336 & \\
\hline Porphyra umbilicalis & Combe Martin, Devon, England, UK & 539 & & DQ191331 & \\
\hline Porphyra umbilicalis & Near Margate, Kent, England, UK & 539 & & DQ191333 & \\
\hline Porphyra umbilicalis & Combe Martin, Devon, England, UK & 539 & & DQ191332 & \\
\hline Porphyra umbilicalis & Sidmouth, UK & & 1387 & & HQ687559 \\
\hline Porphyra umbilicalis & Annapolis Co., NS, Canada & & 1411 & & AF452446 \\
\hline Porphyra umbilicalis & Sand Beach, Bar Harbor, Mount Desert Island, ME, USA & & 1072 & & AY028540 \\
\hline Porphyra umbilicalis & Red Point, Swans Island, ME, USA & & 1070 & & AY028541 \\
\hline Porphyra umbilicalis & Reids State Park, Georgetown, ME, USA & & 1069 & & AY028539 \\
\hline Porphyra umbilicalis & Fort Williams, Portland Head, ME, USA & & 1073 & & AF078747 \\
\hline Porphyra umbilicalis & Two Lights State Park, Cape Elizabeth, ME, USA & & 1063 & & AY028538 \\
\hline Porphyra umbilicalis & New Hampshire, Dover, Dover Point, USA & & 1422 & & AF271077 \\
\hline Porphyra umbilicalis & New Hampshire, New Castle, Jaffrey Point, USA & & 1422 & & AF271076 \\
\hline Porphyra umbilicalis & Nahant Mass, USA & & 1961 & & AB118584 \\
\hline \multicolumn{6}{|l|}{ Pyropia } \\
\hline Pyropia abbottiae & 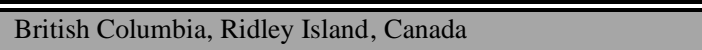 & 745 & 1363 & JN028597 & JN028962 \\
\hline
\end{tabular}




\begin{tabular}{|c|c|c|c|c|c|}
\hline Pyropia abbottiae & Sitka, AK, USA & & 1411 & & AF452423 \\
\hline Pyropia abbottiae & Baker's Beach, Humboldt County, California, USA & & 1349 & & EU223021 \\
\hline Pyropia abbottiae & Peehan, Admiralty Island, Alaska, USA & & 1387 & & EU223022 \\
\hline Pyropia abbottiae & Harling Point, Victoria, British Columbia, Canada & & 1366 & & EU223024 \\
\hline Pyropia abbottiae & Clover Point, Victoria, British Columbia, Canada & & 1366 & & EU223025 \\
\hline Pyropia abbottiae & Harling Point, Victoria, British Columbia, Canada & & 1326 & & EU223027 \\
\hline Pyropia acanthophora & Ponta da Fortaleza, Ubatuba, Sao Paulo, Brazil & 660 & & JN222746 & \\
\hline Pyropia acanthophora & Ponta da Fortaleza, Ubatuba, Sao Paulo, Brazil & 660 & & JN222747 & \\
\hline Pyropia acanthophora & Praia Vermelha do Sul, Ubatuba, Sao Paulo, Brazil & 660 & & JN222749 & \\
\hline Pyropia acanthophora & Praia Dura, Ubatuba, Sao Paulo, Brazil & 660 & & JN222745 & \\
\hline Pyropia acanthophora & Praia Dura, Ubatuba, Sao Paulo, Brazil & 660 & & JN222743 & \\
\hline Pyropia acanthophora & Praia Dura, Ubatuba, Sao Paulo, Brazil & 660 & & JN222744 & \\
\hline Pyropia acanthophora & Ilha Vitória, Ubatuba, Sao Paulo, Brazil & 660 & & JN222748 & \\
\hline Pyropia acanthophora & Praia da Lagoinha, Ubatuba, Sao Paulo, Brazil & 660 & & JN222750 & \\
\hline Pyropia acanthophora & Ubatuba, Sao Paulo, Brazil & & 1507 & & HQ605695 \\
\hline Pyropia aeodis & Paternoster, South Africa & & 1445 & & GU165843 \\
\hline Pyropia brumalis & Vancouver, BC, Canada & & 1366 & & AF452426 \\
\hline Pyropia brumalis & $\begin{array}{l}\text { Third Beach, Stanley Park, Vancouver, British Columbia, } \\
\text { Canada }\end{array}$ & & 1270 & & EU223038 \\
\hline
\end{tabular}




\begin{tabular}{|c|c|c|c|}
\hline Pугоріа сіпnатотеа & Bruce's Rock, Otago, South I, NZ & 1453 & EU521637 \\
\hline Pyropia columbina & Chatham Island, Waitangi Wharf Headland, NZ & 1475 & GU046439 \\
\hline Pyropia columbina & Chatham Island, Ohira, NZ & 1468 & GU046434 \\
\hline Pyropia columbina & Chatham Island, Solomon's Monument, NZ & 1460 & GU046433 \\
\hline Pyropia columbina & South Island, Kings Rock, South Otago, NZ & 1405 & GU046432 \\
\hline Pyropia columbina & Antipodes Island, NZ & 1487 & GU046442 \\
\hline Pyropia columbina & Auckland Islands, Enderby Island, Sandy Bay, NZ & 1472 & GU046437 \\
\hline Pyropia columbina & Auckland Islands, Enderby Island, Sandy Bay, NZ & 1349 & GU046438 \\
\hline Pyropia columbina & $\begin{array}{l}\text { Auckland Islands, Enderby Island, Sandy Bay, south-eastern } \\
\text { corner, NZ }\end{array}$ & 1385 & GU046445 \\
\hline Pyropia columbina & $\begin{array}{l}\text { Auckland Islands, Enderby Island, Sandy Bay, south-eastern } \\
\text { corner, NZ }\end{array}$ & 1496 & GU046447 \\
\hline Pyropia columbina & Auckland Islands, Enderby Island, Sandy Bay, NZ & 1484 & GU046436 \\
\hline Pyropia columbina & Campbell Island, north-eastern cornerof Penguin Bay, NZ & 1400 & GU046444 \\
\hline Pyropia columbina & Falkland Islands, East Falkland, Top Island, Port Stanley, UK & 1391 & GU046423 \\
\hline Pyropia columbina & Falkland Islands, Cape Pembroke, Christina Bay, UK & 1430 & GU046443 \\
\hline Pyropia columbina & Campbell Island, NZ & 1482 & GU046412 \\
\hline Pyropia columbina & Chatham Island, Waitangi Wharf Headland, NZ & 1475 & GU046439 \\
\hline Pyropia conwayae & Lincoln City, Oregon, USA & 1413 & AF452427 \\
\hline
\end{tabular}




\begin{tabular}{|c|c|c|c|c|c|}
\hline Pyropia conwayae & Baker's Beach, Humboldt County, California, USA & & 1353 & & EU223040 \\
\hline Pyropia conwayae & Chesterman Beach, British Columbia, Canada & & 1216 & & EU223043 \\
\hline Pyropia dentata & Shirahama, Chiba, Japan & & 1387 & & HQ687520 \\
\hline Pyropia denticulata & Mooloolaba, Queensland, Australia & & 1352 & & HQ687521 \\
\hline Pyropia fallax & $\begin{array}{l}\text { British Columbia, Murchison Island Lagoon, Gwaii Haanas, } \\
\text { Canada }\end{array}$ & 664 & 1363 & HQ969862 & JN028967 \\
\hline Pyropia fallax & Vancouver, BC, Canada & & 1381 & & AF452429 \\
\hline Pyropia fallax & Clover Point, Victoria, British Columbia, Canada & & 1366 & & EU223056 \\
\hline Pyropia fallax & Harling Point, Victoria, British Columbia, Canada & & 1366 & & EU223057 \\
\hline Pyropia fallax & Surf Bay, Akun Island, Alaska, USA & & 1369 & & EU223058 \\
\hline Pyropia fallax & Surf Bay, Akun Island, Alaska, USA & & 1371 & & EU223059 \\
\hline Pyropia fallax & Surf Bay, Akun Island, Alaska, USA & & 1366 & & EU223060 \\
\hline Pyropia fallax & Surf Bay, Akun Island, Alaska, USA & & 1366 & & EU223061 \\
\hline Pyropia fallax & Katmai Bay, Katmai National Park, Alaska, USA & & 1383 & & EU223063 \\
\hline Pyropia fallax & Akutan Bay, Akutan Island, Alaska, USA & & 1386 & & EU223064 \\
\hline Pyropia fallax & Outside Beach, Cook Inlet, Alaska, USA & & 1364 & & EU223065 \\
\hline Pyropia fallax & Lucy Island, Chatham Sound, British Columbia, Canada & & 1316 & & EU223067 \\
\hline Pyropia fallax & Pasagshak Bay, Kodiak Island, Alaska, USA & & 1296 & & EU223079 \\
\hline Pyropia fallax & Pumicestone Bay, Unalaska Island, Alaska, USA & & 1364 & & EU223083 \\
\hline
\end{tabular}




\begin{tabular}{|c|c|c|c|c|c|}
\hline Pyropia fallax & Shakun Islets, Katmai National Park, Alaska, USA & & 1320 & & EU223084 \\
\hline Pyropia fallax & Avatanak Island, AK, USA & & 1399 & & GU319865 \\
\hline Pyropia fucicola & $\begin{array}{l}\text { British Columbia, Tahsis, Island \#40 on Esperenza Inlet Chart, } \\
\text { Canada }\end{array}$ & 664 & 1363 & JN028614 & JN028969 \\
\hline Pyropia fucicola & Kiukpalik Island, Katmai National Park, Alaska, USA & & 1349 & & EU223086 \\
\hline Pyropia fucicola & Surf Bay, Akun Island, Alaska, USA & & 1368 & & EU223087 \\
\hline Pyropia fucicola & Japonski Island, Sitka Sound, Alaska, USA & & 1359 & & EU223088 \\
\hline Pyropia fucicola & Outside Foul Bay, Afognak Island, Alaska, USA & & 1152 & & EU223090 \\
\hline Pyropia fucicola & Juneau, Alaska, USA & & 1411 & & AF452430 \\
\hline Pyropia gardneri & $\begin{array}{l}\text { British Columbia, Chaatl Island across from Newton Point, } \\
\text { Haida Gwaii, Canada }\end{array}$ & 661 & 1363 & $\begin{array}{l}\text { HM91530 } \\
0\end{array}$ & JN028973 \\
\hline Pyropia haitanensis & Yuge, Ehime, Japan & & 1961 & & $\mathrm{AB} 118585$ \\
\hline Pyropia hiberna & $\begin{array}{l}\text { Foot of 15th Street, Pacific Grove, Monterey County, CA, } \\
\text { USA }\end{array}$ & & 1342 & & GU319866 \\
\hline Pyropia hollenbergii & Agua Verde, Baja California Sur, Mexico & & 1350 & & HQ687523 \\
\hline Pyropia hollenbergii & Bahia Agua Verde, Baja California Sur, Mexico & & 1362 & & AY794401 \\
\hline Pyropia ishigecola & Yoshio, Katsuura, Chiba, Japan & & 1356 & & HQ687524 \\
\hline Pyropia kanakaensis & British Columbia, Bamfield, Seppings, Canada & & 1363 & & JN028978 \\
\hline Pyropia kanakaensis & Kanaka Bay, WA, USA & & 1367 & & AF452431 \\
\hline Pyropia kanakaensis & Baker's Beach, Humboldt County, California, USA & & 1328 & & EU223097 \\
\hline
\end{tabular}




\begin{tabular}{|c|c|c|c|c|c|}
\hline Pyropia kanakaensis & Baker's Beach, Humboldt County, California, USA & & 1359 & & EU223098 \\
\hline Pyropia kanakaensis & $\begin{array}{l}\text { Olympic Peninsula, between Makah Bay and Sekiu, Clallam } \\
\text { County, Washington, USA }\end{array}$ & & 1352 & & EU223099 \\
\hline Pyropia katadae & Ise, Mie, Japan & & 1387 & & HQ687525 \\
\hline Pyropia katadae & Kawatana, Yamaguchi Prefecture, Japan & & 1961 & & AB 118583 \\
\hline Pyropia katadae & Pohang, Gyeongsangbukdo, Korea & & 1441 & & HQ728199 \\
\hline Pyropia katadae & Taiping Corner, Qingdao, China & & 1447 & & DQ630039 \\
\hline Pyropia kinositae & Arito, Suttu, Hokkaido, Japan & & 1496 & & EU521641 \\
\hline Pyropia kinositae & Miyagi, Naruse, Japan & & 1402 & & AB366145 \\
\hline Pyropia kinositae & Hokkaido, Otaru, Shukutsu, Japan & & 1402 & & AB366139 \\
\hline Pyropia koreana & Ohori, Gangwondo, Korea & & 1441 & & HQ728198 \\
\hline Pyropia kuniedae & Sachon, Namhae, Gyeongsangnamdo, Korea & & 1441 & & HQ728200 \\
\hline Pyropia kurogii & British Columbia, Ridley Island, Prince Rupert, Canada & 815 & 1363 & JN028655 & JN028980 \\
\hline Pyropia kurogii & Katmai Bay, Katmai National Park, Alaska, USA & & 1359 & & EU223101 \\
\hline Pyropia kurogii & Udamak Cove, Unalaska Island, Alaska, USA & & 1355 & & EU223102 \\
\hline Pyropia kurogii & Gaada'x, Admiralty Island, Alaska, USA & & 1320 & & EU223103 \\
\hline Pyropia kurogii & Outside Beach, Cook Inlet, Alaska, USA & & 1345 & & EU223104 \\
\hline Pyropia kurogii & Sandy Beach, Sitka Sound, Alaska, USA & & 1345 & & EU223105 \\
\hline Pyropia kurogii & Udamak Cove, Unalaska Island, Alaska, USA & & 1275 & & EU223107 \\
\hline
\end{tabular}




\begin{tabular}{|c|c|c|c|c|c|}
\hline Pyropia kurogii & Portage Bay, Unalaska Island, Alaska, USA & & 1224 & & EU223108 \\
\hline Pyropia kurogii & Juneau, Alaska, USA & & 1411 & & AF452432 \\
\hline Pyropia lacerata & Shirahama, Chiba, Japan & & 1382 & & HQ687527 \\
\hline Pyropia leucosticta & $\begin{array}{l}\text { New Brunswick, Lepreau exposed biodiversity site, Bay of } \\
\text { Fundy, Canada }\end{array}$ & 664 & 1363 & JN028662 & JN028981 \\
\hline Pyropia leucosticta & Smoo, Cave, Durness, Scotland, UK & 524 & & DQ442910 & \\
\hline Pyropia leucosticta & Faroe Islands & 532 & & $\begin{array}{c}\text { AM94339 } \\
8\end{array}$ & \\
\hline Pyropia leucosticta & Berwick-upon-Tweed, Northumberland, England, UK & 539 & & DQ191338 & \\
\hline Pyropia leucosticta & Hannafore Point, Looe, Cornwall, England, UK & 539 & & DQ191337 & \\
\hline Pyropia leucosticta & Sidmouth, UK & & 1387 & & HQ687528 \\
\hline Pyropia leucosticta & New Hampshire, New Castle, Jaffrey Point, USA & & 1422 & & AF271078 \\
\hline Pyropia leucosticta & Gove Point, Cobscook Bay, Lubec, ME, USA & & 1030 & & AF078744 \\
\hline Pyropia leucosticta & Two Lights State Park, Cape Elizabeth, ME, USA & & 1030 & & AY028525 \\
\hline Pyropia moriensis & Otaru, Hokkaido, Japan & & 1431 & & EU521645 \\
\hline Pyropia nereocystis & $\begin{array}{l}\text { British Columbia, Cape Beale, exposed front, Bamfield, } \\
\text { Canada }\end{array}$ & 664 & & JN028685 & \\
\hline Pyropia nereocystis & Sitka, AK, USA & & 1368 & & AF452435 \\
\hline Pyropia nereocystis & Cape Udak, Umnak Island, Alaska, USA & & 1368 & & EU223115 \\
\hline Pyropia nereocystis & Passage Island, Cook Inlet, Alaska, USA & & 1244 & & EU223116 \\
\hline
\end{tabular}




\begin{tabular}{|c|c|c|c|}
\hline Pyropia njordii & Nova Scotia, Lighthouse at Peggys Cove, Canada & $1363 \quad \mathrm{JN} 028693$ & JN028986 \\
\hline Pyropia onoi & Mori, Hokkaido, Japan & 1359 & HQ687529 \\
\hline Pyropia peggicovensis & Nova Scotia, Peggys Cove, Halifax Co., Canada & 1363 & JN028991 \\
\hline Pyropia pendula & Calerita, Baja California Sur, Mexico & 1360 & HQ687530 \\
\hline Pyropia perforata & British Columbia, Qualicum Beach, Canada & 1363 & JN028996 \\
\hline Pyropia perforata & Punta Popotla, Baja California, Mexico & 1448 & GU046416 \\
\hline Pyropia perforata & Sitka, Alaska, USA & 1411 & AF452438 \\
\hline Pyropia perforata & Baker's Beach, Humboldt County, California, USA & 1349 & EU223125 \\
\hline Pyropia perforata & Birch Bay, Whatcom County, Washington, USA & 1353 & EU223126 \\
\hline Pyropia perforata & Crescent City Light, Del Norte County, California, USA & 1367 & EU223127 \\
\hline Pyropia perforata & Clover Point, Victoria, British Columbia, Canada & 1366 & EU223128 \\
\hline Pyropia perforata & Three Saints Bay, Kodiak Island, Alaska, USA & 1348 & EU223129 \\
\hline Pyropia perforata & Campbell River, Vancouver Island, British Columbia, Canada & 1362 & EU223130 \\
\hline Pyropia perforata & Brady's Beach, Barkley Sound, British Columbia, Canada & 1359 & EU223131 \\
\hline Pyropia perforata & Northwest Afognak Island, Alaska, USA & 1366 & EU223132 \\
\hline Pyropia perforata & $\begin{array}{l}\text { North jetty, Humboldt Bay, Humboldt County, California, } \\
\text { USA }\end{array}$ & 1359 & EU223133 \\
\hline Pyropia perforata & South cove, Cape Arago, Coos County, Oregon, USA & 1316 & EU223134 \\
\hline
\end{tabular}




\begin{tabular}{|c|c|c|c|}
\hline Pyropia plicata sp. nov. & Ocean View, Kaikoura, South I, NZ & 1483 & GU046410 \\
\hline Pyropia pseudolanceolata & Harling Point, Victoria, BC, Canada & 1366 & EU223145 \\
\hline Pyropia pseudolanceolata & Amalik Bay, Katmai National Park, Alaska, USA & 1370 & EU223141 \\
\hline Pyropia pseudolanceolata & Akutan Point, Akutan Island, Alaska & 1385 & EU223142 \\
\hline Pyropia pseudolanceolata & Rosario Beach, Skagit County, Washington, USA & 1378 & EU223143 \\
\hline Pyropia pseudolanceolata & Rosario Beach, Skagit County, Washington, USA & 1378 & EU223144 \\
\hline Pyropia pseudolanceolata & Izhut Bay, Afognak Island, Alaska, USA & 1366 & EU223146 \\
\hline Pyropia pseudolanceolata & Outside Big Bay, Shuyak Island, Alaska, Canada & 1366 & EU223147 \\
\hline Pyropia pseudolanceolata & Sedanka Point, Unalaska Island, Alaska, USA & 1365 & EU223148 \\
\hline Pyropia pseudolanceolata & Humpback Bay, Unalaska Island, Alaska, USA & 1351 & EU223149 \\
\hline Pyropia pseudolanceolata & Cape Sitkinak, Sitkinak Island, Alaska, USA & 1385 & EU223150 \\
\hline Pyropia pseudolanceolata & Skan Bay, Unalaska Island, Alaska, USA & 1365 & EU223151 \\
\hline Pyropia pseudolanceolata & $\begin{array}{l}\text { Deadman Bay, San Juan Island, San Juan County, } \\
\text { Washington, USA }\end{array}$ & 1331 & EU223152 \\
\hline Pyropia pseudolanceolata & French Beach, Vancouver Island, British Columbia, Canada & 1385 & EU223153 \\
\hline Pyropia pseudolanceolata & Botany Bay, Strait of Juan de Fuca, British Columbia, Canada & 1387 & EU223154 \\
\hline Pyropia pseudolanceolata & Fishboat Bay, Strait of Juan de Fuca, Canada & 1365 & EU223155 \\
\hline Pyropia pseudolanceolata & $\begin{array}{l}\text { Marine Gardens, Devil's Punchbowl, Lincoln County, Oregon, } \\
\text { USA }\end{array}$ & 1359 & EU223156 \\
\hline
\end{tabular}




\begin{tabular}{|c|c|c|c|c|c|}
\hline Pyropia pseudolanceolata & Perevalnie Passage, Shuyak Island, Alaska, USA & & 1359 & & EU223157 \\
\hline Pyropia pseudolanceolata & Harling Point, Victoria, British Columbia, Canada & & 1291 & & EU223159 \\
\hline Pyropia pseudolanceolata & Northwest Dundas Island, British Columbia, Canada & & 1158 & & EU223162 \\
\hline Pyropia pseudolanceolata & Outside Big Bay, Shuyak Island, Alaska, Canada & & 1179 & & EU223166 \\
\hline Pyropia pseudolinearis & Choshi, Chiba, Japan & & 1387 & & HQ687531 \\
\hline Pyropia pulchella & Waihau Bay East, North Island, NZ & & 1353 & & HQ687532 \\
\hline Pyropia rakiura & Ocean View, Kaikoura, South I, NZ & & 1496 & & EU521646 \\
\hline Pyropia rosengurtii & Faroe Islands & 532 & & & AM943399 \\
\hline Pyropia rosengurtii & England & 539 & & & DQ191335 \\
\hline Pyropia saldanhae & Kommetjie, South Africa & & 1466 & & GU165838 \\
\hline Pyropia seriata & Hondo, Kumamoto, Japan & & 1387 & & HQ687533 \\
\hline Pyropia smithii & $\begin{array}{l}\text { British Columbia, Ramsey Island (point adjacent Kloo Rock), } \\
\text { Gwaii Haanas, Canada }\end{array}$ & 661 & & JN028778 & \\
\hline Pyropia smithii & British Columbia, Alder Island, Gwaii Haanas, Canada & & 1363 & & JN028997 \\
\hline Pyropia smithii & Nudibranch Point, Barkley Sound, British Columbia, Canada & & 1337 & & EU223224 \\
\hline Pyropia sp. 1Cal & California, Jade Cove, USA & 664 & 1358 & JN028786 & JN028999 \\
\hline Pyropia sp. 1POR & $\begin{array}{l}\text { British Columbia, Whiffen Spit, SookeHarbour, Vancouver } \\
\text { Island, Canada }\end{array}$ & 664 & 1363 & JN028790 & JN029001 \\
\hline Pyropia sp. 2Cal & California, McAbee Beach, Monterey, USA & 664 & 1358 & JN028791 & JN029002 \\
\hline
\end{tabular}




\begin{tabular}{|c|c|c|c|c|c|}
\hline Pyropia sp. 551 & Gerringong boat harbor, NSW, Australia & & 1412 & & GU319870 \\
\hline Pyropia sp. 6POR & Texas, South Jetty, Port Arkansas, USA & 664 & 1363 & JN028792 & JN029003 \\
\hline Pyropia sp. AKL170 & Southeast Sandy Bay, Enderby I, Auckland Is, NZ & & 1400 & & GU046403 \\
\hline Pyropia sp. Antar68 & $\begin{array}{l}\text { Admiralty Bay, King George Island, South Shetlands } \\
\text { Archipelago, Antarctica }\end{array}$ & & 1563 & & HQ605698 \\
\hline Pyropia sp. collinsii & Rhode Island, Fort Wetherill, USA & 664 & 1363 & JN028795 & JN029004 \\
\hline Pyropia sp. FAL & Saldamando, Baja California, Mexico & & 1369 & & HQ687535 \\
\hline Pyropia sp. FIA & Top Island, Port Stanley, East Falkland, Falkland Is. & & 1470 & & GU165842 \\
\hline Porphyra sp. FIA & Macquarie Island, Australia & & 1465 & & GU046428 \\
\hline Pyropia sp. FIC & Top Island, Port Stanley, East Falkland, Falkland Is. & & 1449 & & GU046422 \\
\hline Pyropia sp. FID & East Loafers, Sea Lion I, Falkland Is. & & 1476 & & GU046406 \\
\hline Pyropia sp. FID & Top Island, Port Stanley, East Falkland, Falkland Is. & & 1353 & & GU165886 \\
\hline Pyropia sp. FIE & Top Island, Port Stanley, East Falkland, Falkland Is. & & 1479 & & GU046408 \\
\hline Pyropia sp. MIG & Faru de San Miguel, Baja California, Mexico & & 1387 & & HQ687536 \\
\hline Pyropia sp. Piaui & Parnaiba, Piaui, Brazil & & 1562 & & HQ605697 \\
\hline Pyropia sp. PTK & Northwest Bay, Manawa Tawhi, Three Kings Islands, NZ & & 1387 & & HQ687537 \\
\hline Pyropia sp. ROS125 & Henderson Point, North I, NZ & & 1368 & & HQ687538 \\
\hline Porphyra sp. SCL-2008-1 & Harling Point, Victoria, British Columbia, Canada & & 1317 & & EU223013 \\
\hline Porphyra sp. SCL-2008-1 & Peacock Pt, Unalaska Island, Alaska, USA & & 1353 & & EU223018 \\
\hline
\end{tabular}




\begin{tabular}{|c|c|c|c|c|c|}
\hline Porphyra sp. SCL-2008-1 & Helianthus Cove, Akun Island, Alaska, USA & & 1353 & & EU223019 \\
\hline Porphyra sp. SCL-2008-1 & Sedanka Point, Unalaska Island, Alaska, USA & & 1359 & & EU223020 \\
\hline Porphyra sp. SCL-2008-2 & South Head, Cook Inlet, Alaska, USA & & 1328 & & EU223168 \\
\hline Porphyra sp. SCL-2008-2 & Katmai Bay, Katmai National Park, Alaska, USA & & 1360 & & EU223169 \\
\hline Porphyra sp. SCL-2008-2 & Carlisle Island, Alaska, USA & & 1367 & & EU223170 \\
\hline Porphyra sp. SCL-2008-2 & Sarannaya Bay, Kamchatka, Russia & & 1367 & & EU223171 \\
\hline Porphyra sp. SCL-2008-2 & Captains Bay, Amaknak Island, Alaska, USA & & 1125 & & EU223173 \\
\hline Porphyra sp. SCL-2008-2 & Alimuda Bay, Unalaska Island, Alaska, USA & & 1234 & & EU223176 \\
\hline Porphyra sp. SCL-2008-2 & Volcano Bay, Unalaska Island, Alaska, USA & & 1191 & & EU223178 \\
\hline Porphyra sp. SCL-2008-2 & Driftwood Bay, Unalaska Island, Alaska, USA & & 1290 & & EU223180 \\
\hline Porphyra sp. SCL-2008-3 & $\begin{array}{l}\text { Whiffin Spit, Strait of Juan de Fuca, British Columbia, } \\
\text { Canada }\end{array}$ & & 1352 & & EU223138 \\
\hline Porphyra sp. SCL-2008-3 & $\begin{array}{l}\text { Whiffin Spit, Strait of Juan de Fuca, British Columbia, } \\
\text { Canada }\end{array}$ & & 1377 & & EU223139 \\
\hline Porphyra sp. SCL-2008-3 & John Brown's Beach, Japonski Island, Alaska, USA & & 1386 & & EU223140 \\
\hline Pyropia sp. SMR & Curio Bay, Southland, South I, NZ & & 1369 & & HQ687539 \\
\hline Pyropia sp. SSR053 & Ocean View, Kaikoura, South I, NZ & & 1581 & & GU046411 \\
\hline Pyropia sp. SSR091 & Brighton, Otago, South I, NZ & & 1465 & & GU046421 \\
\hline Pyropia sp. stamfordensis & $\begin{array}{l}\text { Rhode Island, Governor Sprague Bridge 17,Narragansett, } \\
\text { USA }\end{array}$ & 664 & 1363 & JN028798 & JN029005 \\
\hline
\end{tabular}




\begin{tabular}{|c|c|c|c|c|c|}
\hline Pyropia sp. STI & Campbell Point, Otago, South I, NZ & & 1376 & & HQ687540 \\
\hline Pyropia sp. TCH243 & Torias Corner, Stewart I, NZ & & 1437 & & GU046418 \\
\hline Pyropia sp. WRO & Punakaiki, Westland, South I, NZ & & 1365 & & HQ687541 \\
\hline Pyropia sp. ZLI1045 & Paternoster, South Africa & & 1465 & & GU165839 \\
\hline Pyropia spiralis & Vila Velha, Espírito Santo, Brazil & 660 & & JN222754 & \\
\hline Pyropia spiralis & Vila Velha, Espírito Santo, Brazil & & 1564 & & HQ605696 \\
\hline Pyropia spiralis & Cibratel, Itanhaém, Sao Paulo, Brazil & 660 & & JN222755 & \\
\hline Pyropia spiralis & Ponta da Armacao, Florianópolis, Santa Catarina, Brazil & 660 & & JN222757 & \\
\hline Pyropia spiralis & Baleia, Sao Sebastiao, Sao Paulo, Brazil & 660 & & JN222758 & \\
\hline Pyropia spiralis & Tijucopava, Guarujá, Sao Paulo, Brazil & 660 & & JN222759 & \\
\hline Pyropia spiralis & Itaipu, Santos, Sao Paulo, Brazil & 660 & & JN222760 & \\
\hline Pyropia spiralis & Lage de Santos, Santos, Sao Paulo & 660 & & JN222756 & \\
\hline Pyropia spiralis & Praia da Lagoinha, Ubatuba, Sao Paulo, Brazil & 660 & & JN222753 & \\
\hline Pyropia suborbiculata & Wonsando, Chungchungnamdo, Korea & & 1441 & & HQ728201 \\
\hline Pyropia suborbiculata & Kanagawa, Yokosuka, Sajim, Japan & & 1961 & & AB287948 \\
\hline Pyropia suborbiculata & Mansonboro Island, NC, USA & & 1066 & & AY028523 \\
\hline Pyropia suborbiculata & Kawatana, Yamaguchi Prefecture, Japan & & 1961 & & $\mathrm{AB} 118580$ \\
\hline Pyropia suborbiculata & Waterford, CT, USA & & 1066 & & AF078743 \\
\hline Pyropia suborbiculata & Fort Fisher, New Hanover Co., NC, USA & & 1326 & & U04041 \\
\hline
\end{tabular}




\begin{tabular}{|c|c|c|c|c|c|}
\hline Pyropia tanegashimensis & Praia Dura, Ubatuba, Sao Paulo, Brazil & 660 & & JN222752 & \\
\hline Pyropia tanegashimensis & Iseki, Tanegashima, Kagoshima, Japan & & 1387 & & HQ687542 \\
\hline Pyropia tenera & Kawaura, Kumamoto, Japan & & 1387 & & HQ687543 \\
\hline Pyropia tenera & Kumamoto, Kawaura, Japan & & 1411 & & AB243206 \\
\hline Pyropia tenera & Kanagawa, Kawasaki, Tonomachi, Japan & & 1402 & & AB366148 \\
\hline Pyropia tenera & Kumamoto, Kuratake, Japan & & 1429 & & AB455544 \\
\hline Pyropia tenera & Kumamoto, Shinwa, Japan & & 1429 & & $\mathrm{AB} 455545$ \\
\hline Pyropia tenera & Mie, Ise, Miyakawa, Japan & & 1429 & & AB455546 \\
\hline Pyropia tenera & Aichi, Toyohashi, Toyokawa, Japan & & 1429 & & AB455547 \\
\hline Pyropia tenera & Kawaura, Kumamoto Prefecture, Japan & & 1961 & & $\mathrm{AB} 118576$ \\
\hline Pyropia tenera & Shinwa, Kumamoto Prefecture, Japan & & 1961 & & AB118577 \\
\hline Pyropia tenera & Soma, Fukushima Prefecture, Japan & & 1961 & & $\mathrm{AB} 118578$ \\
\hline Pyropia tenuipedalis & Urayasu, Chiba, Honshu, Japan & & 1400 & & EU521649 \\
\hline Pyropia tenuipedalis & Yamaguchi, Yamaguchi, Futajima, Japan & & 1961 & & AB287951 \\
\hline Pyropia thuretii & $\begin{array}{l}\text { British Columbia, Tahsis, Island south of Clotchman I., } \\
\text { Spanish Pilot Group, Tahsis, Canada }\end{array}$ & 815 & 1363 & JN028801 & JN029007 \\
\hline Pyropia torta & British Columbia, Alder Island, Gwaii Haanas, Canada & 664 & 1358 & JN028802 & JN029008 \\
\hline Pyropia torta & Sitka, AK, USA & & 1383 & & AF452445 \\
\hline Pyropia torta & Whiffin Spit, Strait of Juan de Fuca, British Columbia, & & 1385 & & EU223229 \\
\hline
\end{tabular}


Canada

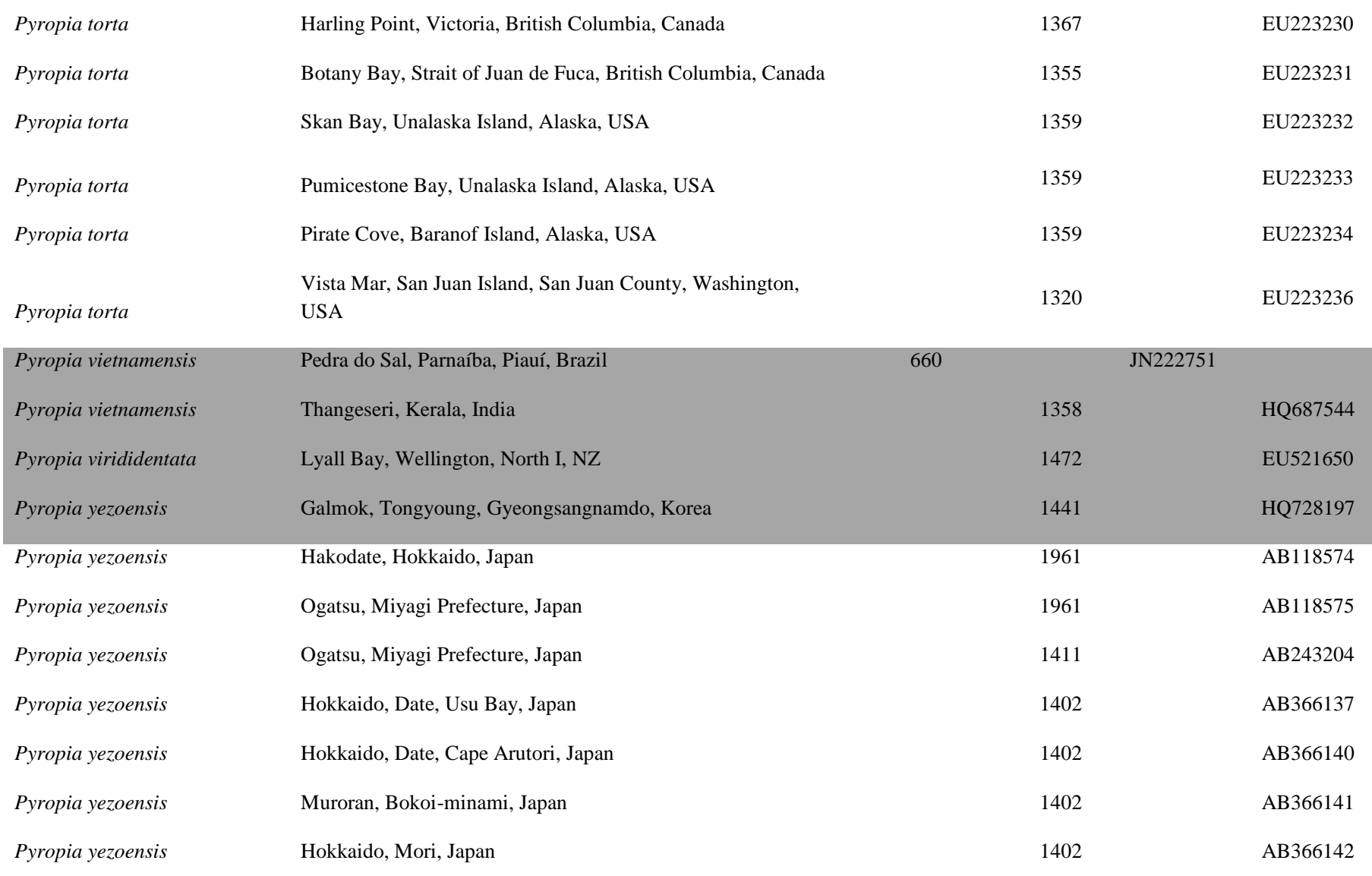




\begin{tabular}{|c|c|c|c|}
\hline Pyropia yezoensis & Miyagi, Naruse, Japan & 1402 & AB366144 \\
\hline Pyropia yezoensis & Miyagi, Shichigahama, Japan & 1402 & AB366147 \\
\hline Pyropia yezoensis & Chiba, Urayasu, Chidori, Japan & 1430 & AB455542 \\
\hline Pyropia yezoensis & Hokkaido, Otaru, Shukutsu, Japan & 1430 & AB455543 \\
\hline Pyropia yezoensis & Eastport, Maine, USA & 1421 & AF021032 \\
\hline Pyropia yezoensis & Cultivated strain & 1961 & AB 118590 \\
\hline Pyropia yezoensis & Cultivated strain & 1467 & DQ227860 \\
\hline Pyropia yezoensis & Cultivated strain & 1467 & DQ227861 \\
\hline Pyropia yezoensis & Cultivated strain & 1467 & DQ227862 \\
\hline Pyropia yezoensis & Cultivated strain & 1467 & DQ227863 \\
\hline Pyropia yezoensis & Cultivated strain & 1467 & DQ227864 \\
\hline Pyropia yezoensis & Cultivated strain & 1467 & DQ227865 \\
\hline Pyropia yezoensis & Cultivated strain & 1467 & DQ227866 \\
\hline
\end{tabular}


444 445

446

447
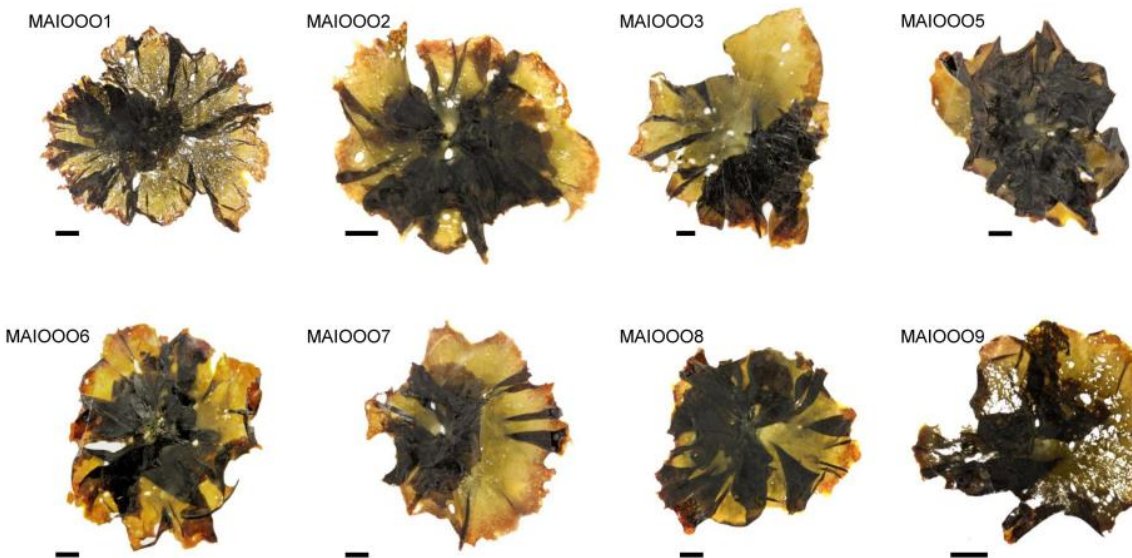

MAIOOO7
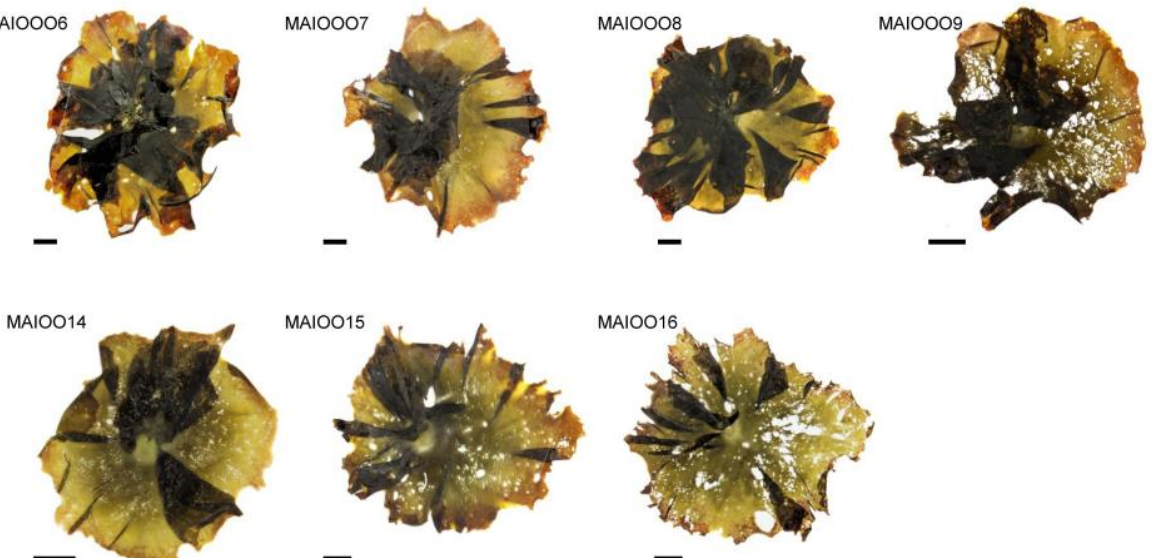

MAIOO15

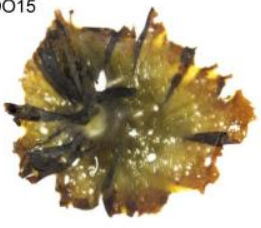

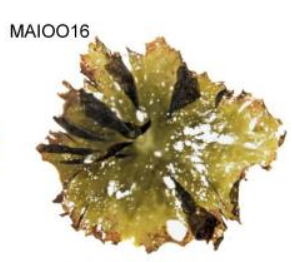

448

449 